ORNL/TM-2000/292

\title{
BIOENERGY FEEDSTOCK DEVELOPMENT PROGRAM STATUS REPORT
}

\author{
L. A. Kszos \\ M. E. Downing \\ L. L. Wright \\ J. H. Cushman \\ S. B. McLaughlin \\ V. R. Tolbert \\ G. A. Tuskan \\ M. E. Walsh
}

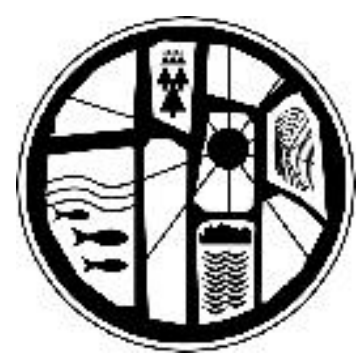


ORNL/TM-2000/92

Environmental Sciences Division

\title{
BIOENERGY FEEDSTOCK DEVELOPMENT PROGRAM* STATUS REPORT
}

\author{
L. A. Kszos, M. E. Downing, L. L. Wright, J. H. Cushman, S. B. McLaughlin, \\ V. R. Tolbert, G. A. Tuskan, and M. E. Walsh
}

Environmental Sciences Division

Publication No. 5049

Date Published: November 2000

\author{
Prepared for the \\ U.S. Department of Energy \\ Office of Fuels Development \\ Budget Activity Number EB 5203000 \\ and \\ Office of Power Technologies \\ Budget Activity Number EB 2404000 \\ Prepared by \\ OAK RIDGE NATIONAL LABORATORY \\ Oak Ridge, Tennessee 37831 \\ managed by \\ UT-BATTELLE, LLC. \\ for the \\ U.S. DEPARTMENT OF ENERGY \\ under contract DE-AC05-00OR22725 \\ *(website address: http:|lwww.bioenergy.ornllbfdpmain.html)
}




\section{CONTENTS}

Page

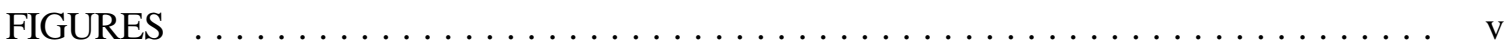

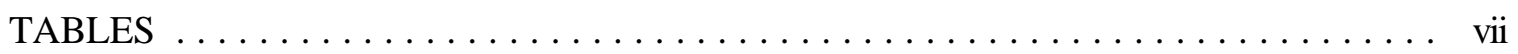

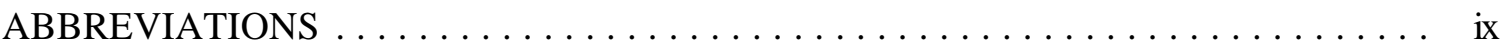

EQUIVALENTS TABLE $\ldots \ldots \ldots \ldots \ldots \ldots \ldots \ldots \ldots \ldots \ldots \ldots \ldots \ldots \ldots \ldots$

EXECUTIVE SUMMARY $\ldots \ldots \ldots \ldots \ldots \ldots \ldots \ldots \ldots \ldots \ldots \ldots \ldots \ldots \ldots \ldots \ldots$

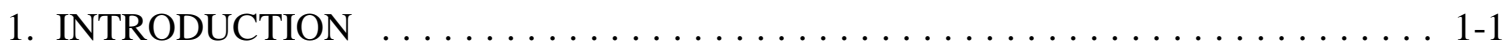

2. ENERGY CROP SELECTION AND BREEDING RESEARCH $\ldots \ldots \ldots \ldots \ldots \ldots .2-1$

2.1 HISTORY OF CROP BREEDING AND SELECTION . . . . . . . . 2-1

2.2 CURRENT CROP SELECTION AND BREEDING

RESEARCH .......................... 2-3

2.2 .1 Woody crops . . . . . . . . . . . . . . . . 2-3

2.2.2 Herbaceous Crops . . . . . . . . . . . . . . . 2-8

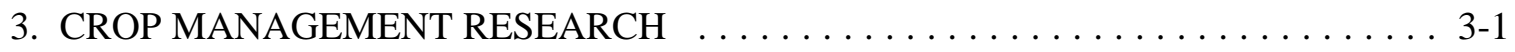

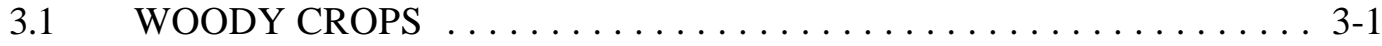

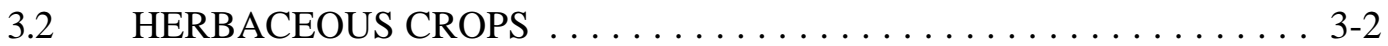

3.3 ENVIRONMENTAL ASSESSMENT AND MONITORING . . . . . . . 3-6

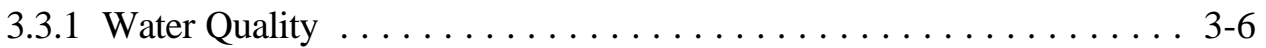

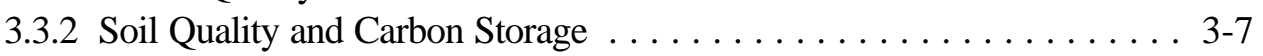

3.3.3 Biodiversity . . . . . . . . . . . . . . . . .

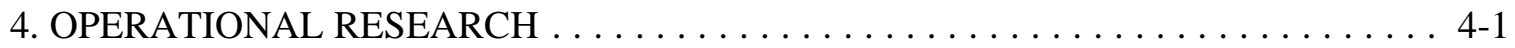

4.1 CROP PRODUCTION OPERATIONAL RESEARCH $\ldots \ldots \ldots \ldots \ldots .4-1$

4.2 SUPPLY LOGISTICS OPERATIONAL RESEARCH AND

DEVELOPMENT ..................... 4-3

4.2.1 Collection of Forest Thinnings and Residues . . . . . . . . . 4-4

4.2.2 Agricultural Residue Supply Logistics . . . . . . . . . . . . . . . 4-4

4.2.3 Energy Crop Harvest and Handling . . . . . . . . . . . . . . . . . 4-5

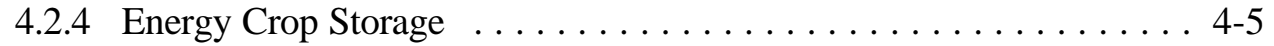

4.2.5 Transactions Costs . . . . . . . . . . . . . . . . 4-5

4.2.6 Analysis and Information Exchange $\ldots \ldots \ldots \ldots \ldots . \ldots .64$

5. INTEGRATED RESOURCE ANALYSIS AND ASSESSMENT RESEARCH . . . . 5 5-1

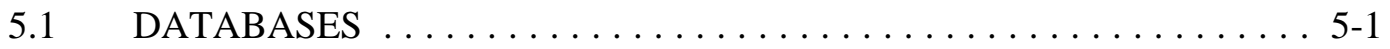

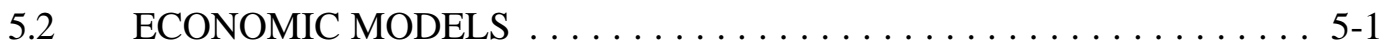


CONTENTS (Continued)

Page

5.3 ECONOMIC AND POLICY ANALYSES $\ldots \ldots \ldots \ldots \ldots \ldots \ldots \ldots \ldots$

5.4 FUTURE RESEARCH DIRECTIONS . . . . . . . . . . . . . . 5-5

6. PARTNERSHIP AND OUTREACH ACTIVITIES $\ldots \ldots \ldots \ldots \ldots \ldots \ldots \ldots \ldots .6$

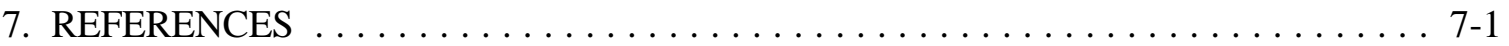




\section{FIGURES}

\section{Page}

2.1 Model woody and herbaceous crops chosen for study in the 1990 s. . . . . . . . . . 2-2

2.2 The crop development concept used for each region. $\ldots \ldots \ldots \ldots \ldots \ldots \ldots$

2.3 Location of crop development and biotechnology centers for woody crop selection and breeding. . . . . . . . . . . . . . . . . . 2-4

2.4 Mid-rotation (after 4 years) yields for the 5 best hybrid poplar clones at

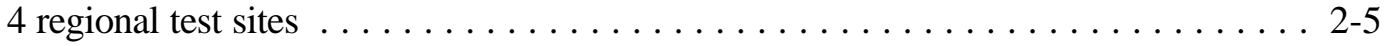

2.5 Mean yield of the best 20 willow and Populus (CARO, NM5, NM6) clones at end of establishment year (1997) in Tully, New York . . . . . . . . . . . . . 2-7

2.6 Six-year-old Populus hybrids in the Pacific Northwest. . . . . . . . . . . . . 2-7

2.7 Location of research activities in the herbaceous crop selection and breeding. . . . 2-9

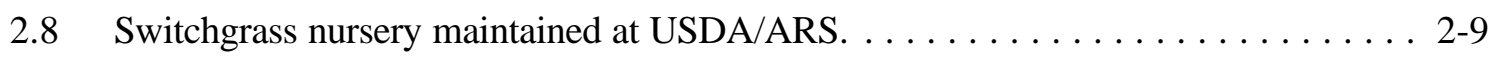

2.9 Average yield (error bars = standard deviation) of Alamo and synthetic switchgrass varieties from breeding program at Oklahoma State University

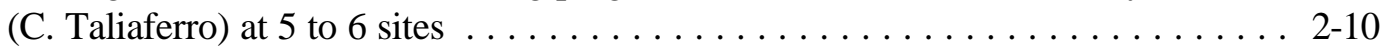

2.10 Production of switchgrass inflorescence from node culture $\ldots \ldots \ldots \ldots \ldots \ldots$ 2-12

3.1 Average switchgrass yields for 1992-1999 at sites in the Virginia Polytechnic Institute and State University program. Stands established in 1992 with exception of Princeton which was established in 1993.

3.2 Average switchgrass yields for 1993-1999 at five Alabama sites in the Auburn University program . . . . . . . . . . . . . . . . . 3-4

3.3 Average switchgrass yield in 1- and 2-cut systems at Knoxville, Tennessee, site . . . 3-6

3.4 Comparisons of sediment losses from biomass crops and agricultural crops show that losses from biomass crops particularly when grown with a cover crop and from no-till agricultural crop production were much lower that from sites maintained weed free. . . . . . . . . . . 3-8

3.5 Soil carbon increased across all depth increments $(0-60 \mathrm{~cm})$ with conversion of traditionally cultivated agricultural land to no-till corn and sweetgum grown with a 60-cm-wide fescue cover crop established midway between rows . . 3-10 
FIGURES (Continued)

\section{Page}

3.6 Bird nest in hybrid poplar planting located near Alexandria, Minnesota. . . . . . . 3-10

4.1 Commercial poplar planting in the Pacific Northwest. . . . . . . . . . . 4-2

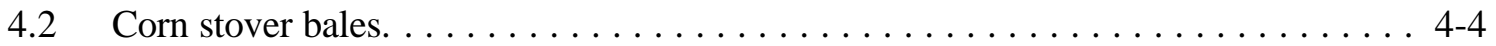

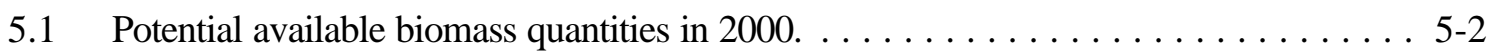

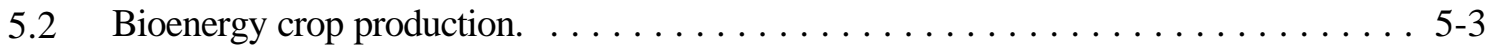

5.3 Consumption of wood and fiber raw materials in pulp, paper, and paperboard production in the United States, 1900-2050 . . . . . . . . . . . . 5-6

5.4 Effects of facility size on corn stover price (50\% corn acres available) $\ldots \ldots \ldots$ 5-6 


\section{TABLES}

Page

2.1 Similarity (\%) among Alamo seed sources based on Nei's Unbiased Genetic

Distance using random amplified polymorphic DNA (RAPD) markers . . . . . . . 2-13 


\section{ABBREVIATIONS}

$\begin{array}{ll}\text { ARS } & \text { Agricultural Research Service } \\ \text { AU } & \text { Auburn University } \\ \text { BEAM } & \text { BioEnergy Information Agency } \\ \text { BFDP } & \text { Bioenergy Feedstock Development Program } \\ \text { C } & \text { carbon } \\ \text { CRP } & \text { Conservation Reserve Program } \\ \text { DNA } & \text { deoxyribonucleic acid } \\ \text { DOE } & \text { Department of Energy } \\ \text { dt } & \text { dry tons } \\ \text { EIA } & \text { Energy Information Agency } \\ \text { EPA } & \text { Environmental Protection Agency } \\ \text { EPRI } & \text { Electric Power Research Institute } \\ \text { FS } & \text { Forest Service } \\ \text { GIS } & \text { Geographic Information System } \\ \text { ISU } & \text { Iowa State University } \\ \text { MPL } & \text { Minnesota Power and Light } \\ \text { N } & \text { nitrogen } \\ \text { NREL } & \text { National Renewable Energy Laboratory } \\ \text { OP } & \text { Office of Policy } \\ \text { ORECCL } & \text { Oak Ridge Energy Crop County Level Database } \\ \text { ORIBAS } & \text { Oak Ridge Integrated Biomass Assessment System } \\ \text { ORNL } & \text { Oak Ridge National Laboratory } \\ \text { OSU } & \text { Oklahoma State University } \\ \text { OTT } & \text { Office of Transportation Technologies } \\ \text { POLYSYS } & \text { Policy Analysis System } \\ \text { R\&D } & \text { research and development } \\ \text { RAPD } & \text { random amplified polymorphic DNA } \\ \text { RC\&D } & \text { Resource Conservation and Development Council } \\ \text { REAP } & \text { Resource Efficient Agricultural Production } \\ \text { SRWC } & \text { short rotation woody crops } \\ \text { SUNY } & \text { State University of New York College of Environmental Science and Forestry } \\ \text { UGA } & \text { University of Georgia, Athens } \\ \text { USDA } & \text { United States Department of Agriculture } \\ \text { USDA/FS } & \text { United States Department of Agriculture/Forest Service } \\ \text { UT } & \text { University of Tennessee, Knoxville } \\ \text { VPI } & \text { Virginia Polytechnic Institute and State University } \\ \end{array}$




\section{EQUIVALENTS TABLE}

\begin{tabular}{|c|c|}
\hline Metric & U.S. Measurement System ${ }^{\mathrm{a}}$ \\
\hline $1.0 \mathrm{Mg}$ or metric tonne & 1.1023 U.S. ton \\
\hline 1.0 hectare & $2.471 \mathrm{acre}$ \\
\hline $1.0 \mathrm{Mg} / \mathrm{ha}$ & 0.446 ton/acre \\
\hline $\begin{array}{c}\text { a Unless otherwise noted in this report, one ton (t) or dry ton }(\mathrm{dt}) \\
\text { refers to a U.S. ton at 0\% moisture content. }\end{array}$ \\
\hline
\end{tabular}




\section{EXECUTIVE SUMMARY}

The U.S. Department of Energy's (DOE's) Bioenergy Feedstock Development Program (BFDP) at Oak Ridge National Laboratory (ORNL) is a mission-oriented program of research and analysis whose goal is to develop and demonstrate cropping systems for producing large quantities of low-cost, high-quality biomass feedstocks for use as liquid biofuels, biomass electric power, and/or bioproducts. The program specifically supports the missions and goals of DOE's Office of Fuels Development and DOE's Office of Power Technologies.

ORNL has provided technical leadership and field management for the BFDP since DOE began energy crop research in 1978. The major components of the BFDP include energy crop selection and breeding; crop management research; environmental assessment and monitoring; crop production and supply logistics operational research; integrated resource analysis and assessment; and communications and outreach. Research into feedstock supply logistics has recently been added and will become an integral component of the program.

\section{Crop Selection and Breeding}

The BFDP's energy crops research emphasizes short-rotation tree crops in the genus Populus (primarily poplars and cottonwoods) and switchgrass (Panicum virgatum). These species were chosen as crop development models based on performance in screening trials, potential for broad distribution, ease of propagation, environmental benefits, and status of genetic information. Many other species are also suitable feedstocks for bioenergy and bioproducts and could become energy crops. Our objective is to improve and protect yields of the model crop species through breeding and sustainable management systems. High, dependable and sustainable yields are key to reducing crop production costs. Genetic improvement and appropriate cultural practices provide the most reliable means of obtaining long-term gains in yield.

The strategy used by BFDP for developing Populus and willow as model woody crops is based on traditional breeding programs linked to plant physiology, molecular genetics, pest and disease resistance, and silviculture practices. Our breeding programs are located in the Pacific Northwest, and in the north-central, southeastern, and northeastern United States. Each regional breeding effort is at a different stage of development. The Pacific Northwest poplar hybridization program started earlier and achieved great success, and the ongoing molecular genetics work is heavily supported by industry. The north-central poplar breeding and testing effort is just beginning to demonstrate in field sites the rewards of hybridization and selection for disease resistance. In the north-central regions, new non-commercial hybrid poplar clones have demonstrated growth rates that are significantly greater than those of commercial controls. In the southeastern region, eastern cottonwood clone bank nurseries and clonal breeding trials have been established. In the northeastern region, selection and breeding of hybrid willow involves native germplasm collection, breeding and selection, and field trials. Growth data indicate that some of the new clones will outperform those previously planted in field trials.

Several woody crops studies have relevance nationwide. Detailed physiological studies of growth limitations in several hardwood species were conducted in the Southeast. Evaluations of the mechanisms of drought stress resistance among several hybrid poplar clones are providing input to industry breeding programs. Applying the tools of biotechnology to woody crop selection and breeding is expected to accelerate progress in woody crop improvement.

The BFDP is a participating member in two biotechnological cooperatives. Recently, researchers with the Poplar Molecular Genetic Cooperative isolated the gene that confers resistance 
to an important Populus disease, leaf rust caused by Melampsora medusa. The Tree Genetic Engineering Research Cooperative is currently transforming commercially important hybrid poplar clones with sterility genes, insect resistance genes, and herbicide resistance genes. At ORNL, researchers are using mathematical models and molecular genetic assays to understand the genetic mechanisms of sexual differentiation and wood formation in willow.

Switchgrass development is centered around breeding programs in Nebraska, Oklahoma, and Georgia. Current breeding projects build upon early work that identified chromosomal and cytological differences between upland and lowland switchgrass cultivars and emphasize genotypic recurrent selection. Thus far, many of the experimental synthetic varieties bred over the past few years are producing significantly more biomass than commercial controls. New molecular tools are being developed to explore the biology of switchgrass, to improve classical breeding, and to set the stage for potential gains through genetic transformation (if deemed desirable). These tools include development of tissue culture techniques for clonal reproduction of parent plants, molecular fingerprinting, genetic mapping, and linking physiological traits to specific genotypes. Significant advances have been made in tissue culture technology since 1993, including the development of plantlets from a wide variety of plant parts, production of flowers in culture, and techniques for producing plantlets from cells in suspension cultures.

\section{Crop Management Research}

Woody crop management research has been an integral component of the BFDP since its inception. Although many silviculture issues are sufficiently resolved to result in successful establishment and production, most management issues - such as rapid increase of preferred clones, fertilization, weed control, and disease and insect control - must be optimized at the regionor site-specific level and thus are not resolved at all locations. Insects and disease have the potential to seriously hinder the development of woody species as energy crops. Research at several institutions is focused on developing new cottonwood clones that are resistant to the cottonwood leaf beetle, Septoria stem canker, and Melampsora leaf rust.

Crop management research for switchgrass focuses on improving practices or conditions that constrain the use of switchgrass for energy. These constraints may be related to planting, stand establishment, use of chemicals for fertilizer, weed or pest control, soil quality, or harvest regime. Establishment issues, such as seed dormancy, seed scale-up, and the use of herbicides and/or insecticides, are important because of their potential impacts on cost. Successful stand establishment practices have been developed for the Southeast, including use of methods to break seed dormancy, effective application of fertilizers (N, P, and K), and herbicide regimes. Although much progress in establishment has been accomplished, research efforts are continuing to optimize establishment in all regions.

\section{Environmental assessment and monitoring}

In the process of developing feedstocks, it is important to develop the quantitative data needed to identify the environmental benefits and risks associated with establishment, management, and harvest of bioenergy crops and their use for energy. Water quality issues are increasingly becoming a concern because of the potential transport of herbicides and nutrients into surface water and groundwater. Studies in small watersheds have been conducted in the Southeast to evaluate erosion, surface water quality and quantity, and subsurface movement of water and nutrients from woody and herbaceous crops. A watershed study in South Carolina is evaluating the effects of water level manipulation on water quality and quantity, soil quality, and short rotation woody crop productivity. 
An integral component of environmental studies of biomass crops is to quantify the changes that occur in soil quality and soil carbon storage for a variety of management practices, soil types, and climates. Soil carbon sequestration and soil quality in areas with switchgrass plantings are currently being investigated in the southeast. In the near future, similar research will be initiated in the northern Great Plains region. Early indications are that soil improvement may be occurring in areas planted with switchgrass. In the Southeast, a model based on soil organic carbon measurements has been developed to predict the rate of increase in soil organic carbon after switchgrass establishment.

Recently, BFDP has worked with the United States Department of Agriculture (USDA) Agricultural Research Service to begin studies on the use of agricultural residue, particularly corn stover, for energy production. This research will be part of an effort to identify stover availability and harvest potential while maintaining soil cover, soil stability, and soil quality.

The role of energy crops in enhancing biodiversity has been an area of research since 1992. From 1992 to 1996, bird and mammal surveys were conducted in areas that contained various types, sizes, and ages of energy crops and undisturbed habitats. In general, established hybrid poplar plantings were used more extensively by birds and small mammals than common row crops but less extensively than natural mixed forests. In the Southeast, bird community structure and diversity in industrial plantings of sweetgum and sycamore were comparable to community structure and diversity in similarly aged hardwood forests.

\section{Operational Research}

Operational research involves the collection and analysis of data from commercial-scale or demonstration-scale plantings. The objective is to understand and improve overall system efficiency and reduce costs of feedstock supplies. The BFDP has been engaged in operational research since the North Central Hybrid Poplar Regional Planting established approximately 130 acres of hybrid poplar in the late 1980s. In 1994 and 1995, the BFDP and others collaboratively established approximately 5000 acres of hybrid poplar in two Minnesota projects. Production and operational data from these plantings are being collected and published for use by the bioenergy community. The BFDP is working with collaborators in projects established through the DOE Biomass Power Program. For these switchgrass and willow production systems, the planting, field preparation, harvesting, transporting, and processing costs are being tracked and recorded.

Supply logistics research, only recently added as a component of the BFDP program, focuses on the equipment, systems, and infrastructures required to move biomass from where it is grown to where it is used, in a form needed by the end-user. We are collaborating with the National Renewable Energy Laboratory (NREL) on a model of the logistics and costs of collecting, transporting, and processing corn stover for use as an ethanol feedstock. The results will be linked to the ethanol conversion models developed by NREL to obtain full supply-chain economics.

\section{Integrated Resource Analysis and Assessment}

Integrated resource analysis and assessment research uses information from BFDP tasks and DOE programs to analyze economic factors associated with biomass production. The work involves creation of tools, models, and databases that can be used by firms, government agencies, and other institutions to conduct analyses pertinent to their needs. Our analysis focuses on regional and national issues and provides information in the form of databases and user-friendly models that can be used by individual firms to conduct screening and pre-feasibility analysis. The Oak Ridge Energy Crop County Level Database (ORECCL) includes county-level land-use information and information about three energy crops, including expected yields and range and estimated production 
costs. The Multi-Feedstock Biomass Resource Database contains estimated price and quantity data for forest residues, mill residues, urban wood wastes, agricultural residues, and dedicated energy crops. Economic models that have been developed include (1) BIOCOST, a model used to estimate regional costs of producing switchgrass, hybrid poplar, and willow; (2) the Oak Ridge Integrated Biomass Assessment System (ORIBAS), a geographic information system (GIS)-based transportation model; and (3) the Policy Analysis System (POLYSYS), an agricultural sector model used to estimate the cost-competitiveness and impacts of biomass crops with traditional agricultural land uses.

\section{Economic and policy analyses}

The databases and economic models are currently being used in several economic and policy analyses. One recent analysis indicates that if biomass could be sold at a $\$ 40 /$ dry ton farmgate price, approximately 42 million acres (producing 188 million dry tons of biomass) could produce energy crops at a profit greater than that from existing uses of the land. In a joint analysis with the USDA Forest Service, we are evaluating the potential role for hybrid poplar in fiber markets.

Corn stover is an existing form of biomass that could be collected and processed to produce ethanol as a liquid transportation fuel. A study is currently analyzing the potential economic impacts of a corn-stover-to-ethanol industry in the ten Midwestern states that produce the greatest quantities of corn. The analysis, conducted for each state, will include one-time impacts associated with the construction of ethanol plants, as well as annual impacts associated with plant operation, the agricultural sector, and the transportation sector.

\section{Partnership and Outreach}

The BFDP strives to provide useful, accurate information on energy crop research, biomass resources, and biomass production. All BFDP staff communicate with public and technical audiences through such activities as farm show participation, International Energy Agency task participation, contribution to web sites, BFDP's Energy Crops Forum newsletter, and fact sheets or Frequently Asked Questions sheets. In addition, staff members have participated actively in meetings with environmental constituencies across the country to provide input and to identify, define, and document the interests and concerns that internal and external stakeholders have about bioenergy crops and agricultural residues, cultivation, and harvesting practices. 


\section{INTRODUCTION}

The U.S. Department of Energy's (DOE) Bioenergy Feedstock Development Program (BFDP) is a mission-oriented program of research and analysis whose goal is to develop and demonstrate environmentally acceptable crops and cropping systems for producing large quantities of low-cost, high-quality biomass feedstocks. These feedstocks may be used for liquid biofuels, biomass electric power, and/or bioproducts. The program specifically supports the missions and goals of DOE's Office of Fuels Development and DOE's Office of Power Technologies who jointly provide major funding for the program.

Oak Ridge National Laboratory (ORNL) has provided technical leadership and field management for BFDP since DOE began energy crop research in 1978. The major components of the BFDP include the development of energy crop and residue resources, research on environmental issues related the production of energy crops and the collection of residues for energy uses, integrated economic and resource assessments, support and evaluation for development and demonstration projects, and stakeholder communications. Feedstock supply logistics efforts have recently been added and will become an integral component of the program.

The BFDP's energy crops research emphasizes short-rotation tree crops in the genus Populus (primarily poplars and cottonwoods) and switchgrass (Panicum virgatum). The research and development strategy used by BFDP for developing energy crops is to create virtual "Crop Development Centers" within a region by facilitating collaboration among the best experts available. This strategy relies heavily on traditional genetic improvement approaches. One core institution conducts the breeding, while others are recruited to conduct clone or variety trials and supporting research. Linkages among researchers and institutions are facilitated by the BFDP to ensure that information from plant physiology, molecular genetics and biotechnology, pest and disease resistance, and silvicultural/agronomic studies are integrated into the breeding process. ORNL staff ensure the continual exchange of information and plant materials among regional cooperators as well as enhance the crop development efforts with basic physiological and biotechnology research. BFDP's crop development research is complemented by resource assessments, economic analysis, and environmental research and analysis that provide the information needed to demonstrate and commercialize biomass energy systems. Its environmental research, designed to ensure that feedstock production systems are sustainable and environmentally beneficial, emphasizes water quality impacts, soil sustainability, carbon sequestration and cycling, and biodiversity.

The BFDP includes analysis of potential resource supplies and demands to provide timely and relevant information to public and private organizations interested in biomass energy development. Work in this area incorporates information from all BFDP research areas and from the U.S. Department of Agriculture (USDA). It supports short-term information responses and the longerterm development of databases and analytical tools. To facilitate collaboration with other organizations interested in bioenergy, the BFDP strives to use existing and accepted models, databases, and methods, especially ones used by the USDA.

The project support and evaluation activity provides a central contact for companies and individuals needing information on feedstocks and market development at the larger scale. Data and information from experiences with larger-scale feedstock supply systems are, in turn, fed back into the program's research and analysis elements. With an increasing number of individuals and 
organizations assessing the potential importance of biomass energy, the BFDP places a strong emphasis on providing consistent and documented data and information.

This status report is organized as follows. First, the history of current crop breeding and selection is reviewed. This is followed by a three-part section on crop management research including woody crops, herbaceous crops, and environmental sustainability. The last three sections of this report include a discussion of operational logistics research, integrated resource analysis and assessment research, and a final section on outreach and partnerships that includes a list of current research projects and collaborators arranged according to geographic region. The report is extensively annotated with references that are available through BFDP or from specific research collaborators. 


\section{ENERGY CROP SELECTION AND BREEDING RESEARCH}

BFDP at ORNL has been conducting research for DOE since 1978 to identify and develop fast-growing trees and herbaceous crops. The research and development (R\&D) strategy used by BFDP recognizes that each region of the country may require different plant materials and different agronomic approaches in order to obtain economically competitive and environmentally acceptable crop production systems. However, the types of R\&D required in each region are similar, and some of the more basic elements of the research are applicable across regions. Our near-term objective has been to optimize current production efficiency with a longer term objective of improving and protecting yields through breeding and technology. Increases in yield are the key factor to reducing crop production costs, and genetic improvement along with appropriate cultural practices provide the most reliable means of obtaining long-term gains in yield. Dramatic changes in biotechnology during the past 5 to10 years have greatly increased the opportunities for genetic gains.

\subsection{HISTORY OF CROP BREEDING AND SELECTION}

In the 1980s the focus of BFDP was on identifying the best species and geographical regions for further examination. Many collaborators from universities and the USDA were selected based on technical competency and geographic location. Well over 100 woody species and 35 herbaceous species were evaluated for their potential to produce high yields over broad geographical areas. The evaluation was based on a combination of newly established species comparison trials and evaluation of previously established trials.

The woody crops selection and breeding research in the early 1980s focused on improving the productivity of short rotation woody crops (SRWC) through testing, selecting, and genetically improving species and clones of trees and shrubs for use in intensively managed systems. The most promising areas for development based on land availability were located in the South and Lake States, though the Pacific Northwest provided the model for rapid production systems. By 1984, BFDP was able to identify and rank 22 hardwood species that were most promising for wood energy feedstock plantations. ${ }^{1}$ The results of the early screening studies are found in BFDP documents. 2, 3, 4, 5 Of the 22 hardwood species identified, four "model" species and a genus were identified for detailed research: cottonwoods and poplars (genus Populus), sweetgum (Liquidambar styraciflua), silver maple (Acer saccharinum), black locust (Robinia pseudoacacia), and American sycamore (Platanus occidentalis). ${ }^{6,7,8,9,10}$ Other species that were identified as potentially important include willow (Salix spp), alder (Alnus spp.), eucalyptus (Eucalyptus spp.), and mesquite (Prosopis spp.). Selection criteria for parent trees and their progeny included narrow crowns, high energy content, high specific gravity, coppice ability, pest resistance, and high per-unit-area productivity. ${ }^{6}$ Genetic improvement programs, silvicultural studies, and basic research projects across the United States were initiated (Fig. 2.1), and some progress was made on silver maple, ${ }^{11,12}$ eucalyptus, ${ }^{13}$ black locust,${ }^{14,}{ }^{15}$ alder, ${ }^{16,17}$ mesquite, ${ }^{18,}{ }^{19}$ and sycamore. ${ }^{20}$

Our focus today is on Populus in the Pacific Northwest, as well as the north-central and southeastern United States, and on hybrid willow in the Northeast. The remaining species have mostly been eliminated from the program because of fiscal constraints, lack of demonstrated productivity, limited site adaptability, difficulties during the biochemical conversion process to ethanol, or a combination of several of these factors. Because it is recognized that species diversity would reduce the risks associated with supply, our early work with multiple species will be valuable should funds become available to continue development of additional species. 


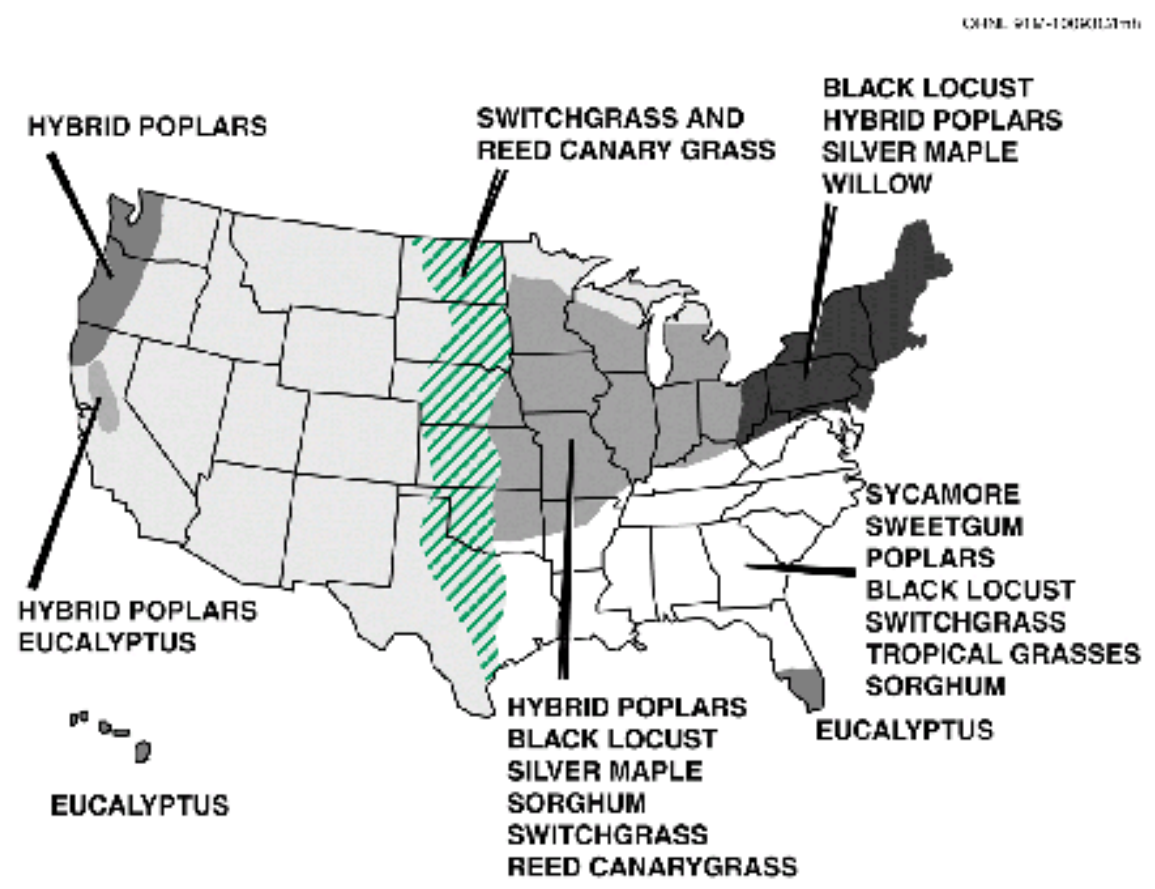

Fig. 2.1. Model woody and herbaceous crops chosen for study in the 1990s.

In 1984, field studies were begun to screen and select promising lignocellulosic herbaceous crop species (annual and perennial grasses and perennial legumes). Projects were started in the Southeast [Auburn University (AU) and Virginia Polytechnic Institute and State University (VPI)] and Midwest and Lake states (Cornell University, Geophyta, and Purdue University). These areas were chosen because they included large areas of cropland with relatively few environmental restrictions on productivity (e.g, temperature or moisture extremes). In 1988, screening trials were started in the Great Plains [Iowa State University (ISU) and North Dakota State University]. Each project compared a number of species under a range of management intensities on a range of sites from good cropland to cropland marginal for conventional row crops (Fig. 2.1). Results from these early trials are available in BFDP reports ${ }^{21,22,23,24,25,26,27}$ and in publications by the investigators. $^{28,29,30,31,32,33,34,35,36}$

In 1991, the decision was made to focus herbaceous crop research on switchgrass, ${ }^{37,}, 38$ which is a high-yielding perennial grass species with potential for widespread use in the United States. As with SRWC research, the rationale for use of a model species was to concentrate our efforts and resources in order to improve the overall efficiency of the many interrelated aspects of research that are requisite for bioenergy production. Some selections of switchgrass varieties during the species screening trials demonstrated high within-species variability in yield potential and the likelihood that gains in yield could be achieved through additional breeding. ${ }^{31}$ Six new projects were initiated in 1992 in the areas of yield management (3 projects), breeding (1 project), and basic studies of biological processes ( 2 projects), including physiology, soil carbon dynamics, and biotechnology. 


\subsection{CURRENT CROP SELECTION AND BREEDING RESEARCH}

Genetically improving Populus, willow, and switchgrass through selection and breeding research is a key component of BFDP. Enhancing such traits as drought resistance, pest and disease resistance, and growth is vital for developing bioenergy crops. Genetic improvements combined with appropriate cultural practices provide the most reliable means of obtaining long-term gains in yield.

\subsubsection{Woody Crops}

The current R\&D strategy used by BFDP for developing Populus and willow as model woody crops is shown in Fig. 2.2. This strategy is based on traditional genetic improvement programs and clone-site trials with linkages designed to gain an understanding of plant physiology, molecular genetics, pest and disease resistance, and silviculture issues. ${ }^{39}$ The integration of biotechnology into traditional breeding projects is leading to increased yields, improved adaptability, and acquired pest resistance. Our core regional breeding programs are located in the north-central, northeastern, and southeastern United States. The current network of research sites encompassing regional field trials and testing sites, conventional breeding activity, and basic research is shown in Fig. 2.3. The BFDP strategy, results, and directions for woody crop research were recently detailed in Wright and Tuskan ${ }^{39}$ and Tuskan. ${ }^{40}$

Breeding and selection efforts for poplars and willow have moved into advanced generation breeding strategies involving both interspecific and intraspecific hybridization. Heterosis, or hybrid vigor, has been demonstrated in numerous crosses involving either species. ${ }^{41}$ Here, the hybrid progeny outperforms either parent. The selection criteria have focused on improvements in productivity and disease and pest resistance. Improvements in energy content (e.g., by increasing

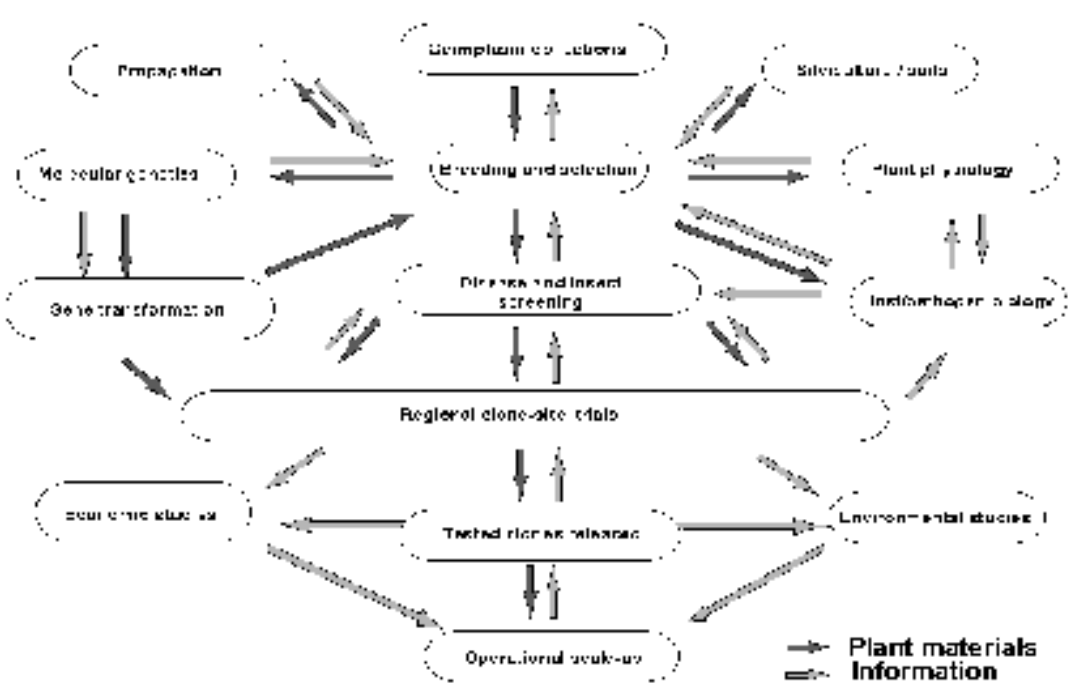

Fig. 2.2. The crop development concept used for each region. 


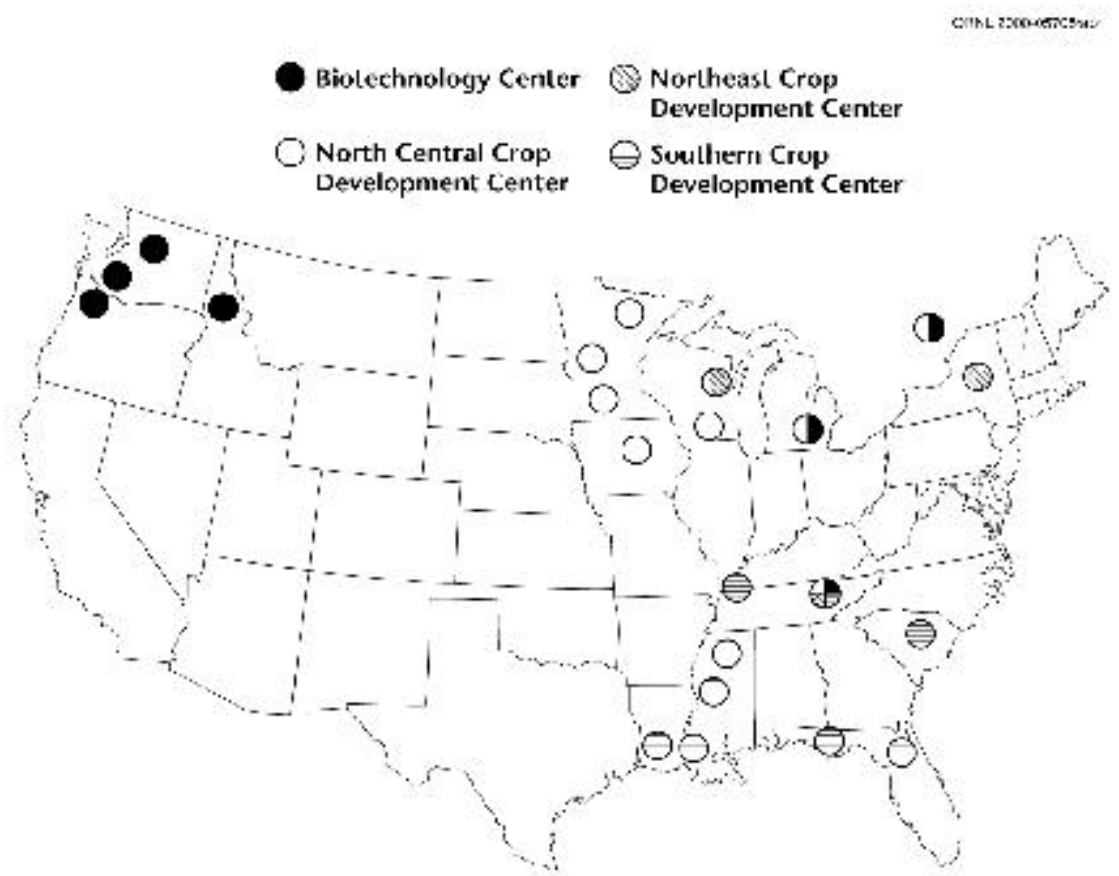

Fig. 2.3. Location of crop development and biotechnology centers for woody crop selection and breeding.

density) and fiber properties may become important in the use of these species for energy and bioproduct formulations, so expansion of selection criteria is being evaluated.

Traditional breeding and selection work with hybrid poplar and eastern cottonwood is ongoing in the north-central United States with funding primarily to the USDA Forest Service (USDA/FS) and ISU. The development of clones for regional testing takes place, in part, at ISU and the University of Minnesota where, recently, twenty new cottonwood clones were evaluated in nursery trials. The new clones were selected on the basis of relative performance to commercial checks and then clonally propagated for inclusion in regional tests. In addition, thirty-one clones from previous regional tests were identified as ready for full-scale testing in operational plantations. During 1995 and 1997, clonal trials were established in Minnesota, Iowa, Wisconsin, and Michigan using Populus clones obtained from ISU and the University of Minnesota. This work has demonstrated that clones bred and selected in Iowa performed well at the Iowa and Wisconsin test sites while clones bred and selected in Minnesota performed well at the Minnesota and Wisconsin test sites (D. E. Riemenschneider, USDA/FS, personal communication). Thus, opportunities to transfer clones between breeding programs in Minnesota and Iowa may be limited. Some experimental clones have demonstrated growth rates that are significantly greater than the commercial controls (Fig. 2.4). For example, mean aboveground increment biomass for two controls at 4 years was $3.0 \mathrm{Mg} / \mathrm{ha} /$ year $(1.3 \mathrm{dt} / \mathrm{ac} /$ year $)$ in Minnesota and for the best clone was 3.9 $\mathrm{Mg} / \mathrm{ha} /$ year (1.7 dt/acre/year) (D. E. Riemenschneider, USDA/FS, personal communication). It is anticipated that the final yield (8-10 years) for the control in Minnesota will be $9.0 \mathrm{Mg} / \mathrm{ha} / \mathrm{y}$ (4 dt/acre/year). 


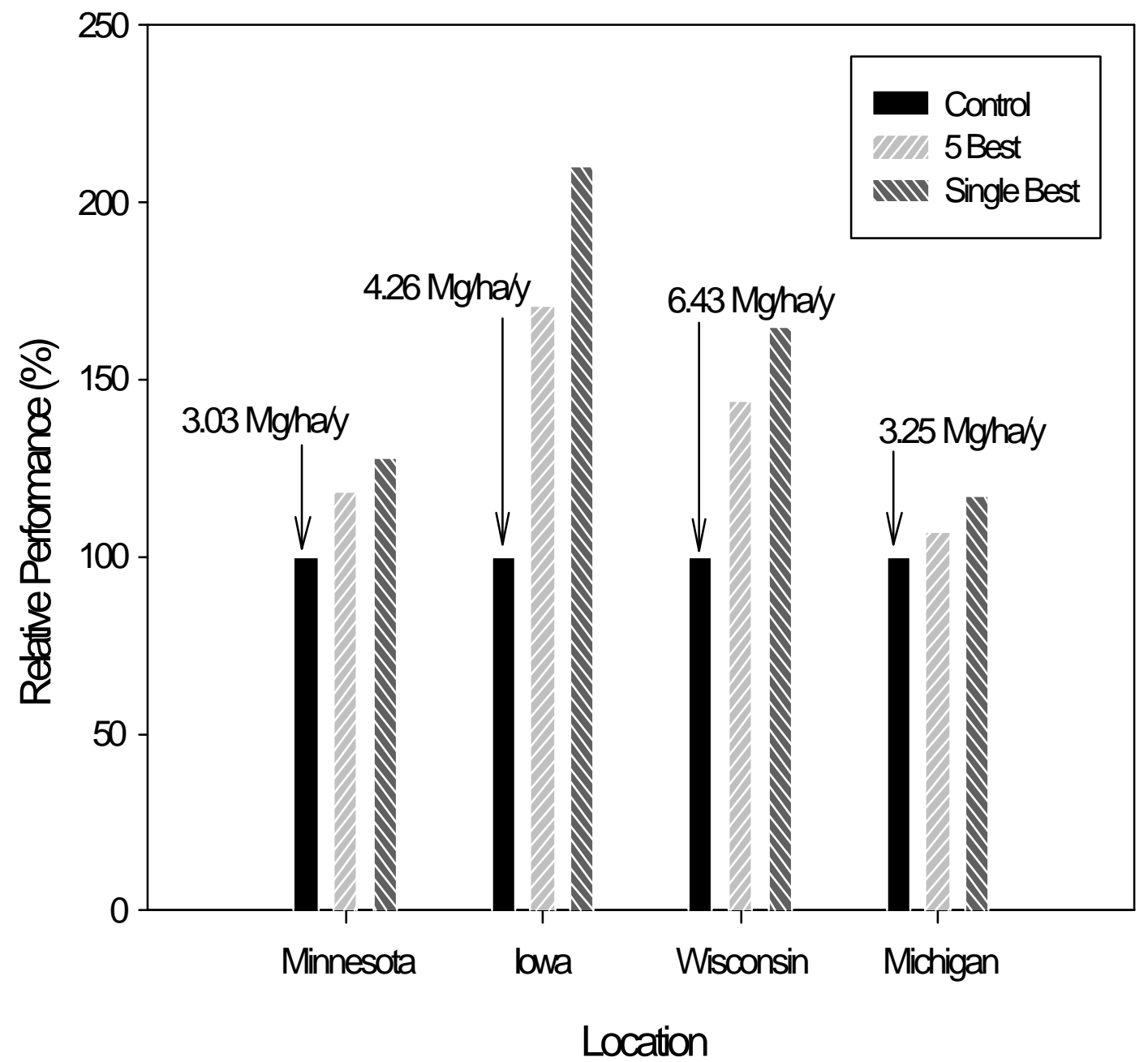

Fig. 2-4. Mid-rotation (after 4 years) for the 5 best hybrid poplar clones at 4 regional test sites. Controls are clones DN34 and NM6. Source: D. Riemenschneider, USDA Forest Service.

Breeding and selection in the southeastern region of the United States also focuses on the eastern cottonwood, although additional species, such as sycamore, sweetgum, and black locust remain under consideration. ${ }^{42,}{ }^{43}$ Mississippi State University in collaboration with Louisiana State University, University of Florida, and private industry have established clone bank nurseries, clonal breeding trials, and begun work to use genetic markers to "fingerprint" tested clones. Field tests have been established in Florida, Missouri, Alabama, and North Carolina. ${ }^{44,45}$ An expanded breeding effort for the Southeast will be initiated in the near future. Also in the Southeast, researchers collaborating under a cooperative research and development agreement 
have been investigating the factors that limit productivity of tree growth in the southeastern United States. Fifth-year field results from a fertilizer-by-irrigation growth study, containing cottonwood, sycamore, and sweetgum, indicated that long-term limitations on growth in the southeastern United States cannot be overcome by simple water and/or fertilizer supplements. Supplemental water and/or fertilizer did initially increase growth rates, mirroring those seen in the Pacific Northwest, but by year three, at the point of crown closure, these supplements did not allow for continued accelerated growth. Species differences in growth rate were correlated with photosynthesis/ respiration rates, but clonal differences within species were not. It appears that the largest single factor contributing to superior growth is genetic selection of clonal materials suited for short-rotation silviculture (e.g., straight stems, fast growth, disease resistant).

Unlike in other regions of the United States, the primary model woody crop species for the northeastern region is hybrid willow. This is primarily because of the high productivity of hybrid willow in the cooler climates of the Northeast. The current BFDP effort in selection and breeding through the State University of New York (SUNY) College of Environmental Science and Forestry involves germ plasm collection, breeding and selection, and field trials. ${ }^{46}$ A genetic selection trial with hybrid willow clones was established in 1997 in cooperation with USDA/FS in Wisconsin and Michigan using clones developed mainly in Canada. The range in yields obtained for willow clones is shown in Fig. 2.5. A new hybrid willow project was initiated in 1999 to create alternative willow clones specifically adapted to the Northeast and northern portions of the north-central United States.

The biotechnological approaches to woody crop selection and breeding are expected to continue to increase genetic gains over those achievable using traditional breeding efforts. A discussion of the molecular techniques available with emphasis on the potential impacts on breeding progress is given by Dinus and Tuskan. ${ }^{47} \mathrm{~A}$ technological breakthrough occurred with the identification and use of molecular markers in marker-aided selection strategies. In 1995, documented progress was made in developing a molecular map for hybrid poplar ${ }^{48}$ and identifying markers for various traits (e.g., drought tolerance and disease resistance). ${ }^{49}$ These markers continue to be used to increase the efficiency of the selection and breeding process. Advances in biotechnology funded by BFDP between 1987 and 1997 include the establishment of field tests of (1) tissue culture propagated silver maple, ${ }^{50}$ (2) somoclonal variants for disease resistance and herbicide resistance in hybrid poplar, ${ }^{51}$ and (3) genetic tranformants expressing herbicide resistance, ${ }^{52}$ insect resistance, and male sterility. ${ }^{53}$

Currently, BFDP efforts in genetic improvement through biotechnological approaches are centered at the University of Washington and Oregon State University. The Poplar Molecular Genetic Cooperative at the University of Washington focuses on intercrossing five species of Populus with proven value for bioenergy plantations. Interspecific hybrids from these species achieve, with fertilizer application, 11-22 Mg/ha/year (5-10 dry tons/acre/year) with average maximum yields reported at $31 \mathrm{Mg} / \mathrm{ha} /$ year (14 dry tons/acre/year; Fig. 2.6).$^{54}$ Molecular tools, such as genetic markers and DNA libraries, are being used to unite genetic maps among poplar pedigrees, determine clonal identity, test for paternity, and estimate gene flow from plantation forests into native stands. Recently, the gene that confers resistance to an important Populus disease (leaf rust caused by Melampsora medusa) ${ }^{55}$ has been isolated. Field trials are currently being conducted in the Pacific Northwest to verify disease resistance in populations containing the isolated gene. This region also contains the only BFDP-supported genetic transformation effort. The Tree Genetic Engineering Research Cooperative at Oregon State University is currently transforming ${ }^{56}$ commercially important hybrid poplar clones with sterility genes ${ }^{57}$ insect resistance genes, and herbicide (e.g., glyphosphate or Roundup $\left.{ }^{\circledR}\right)^{58}$ resistance genes. These transformed 


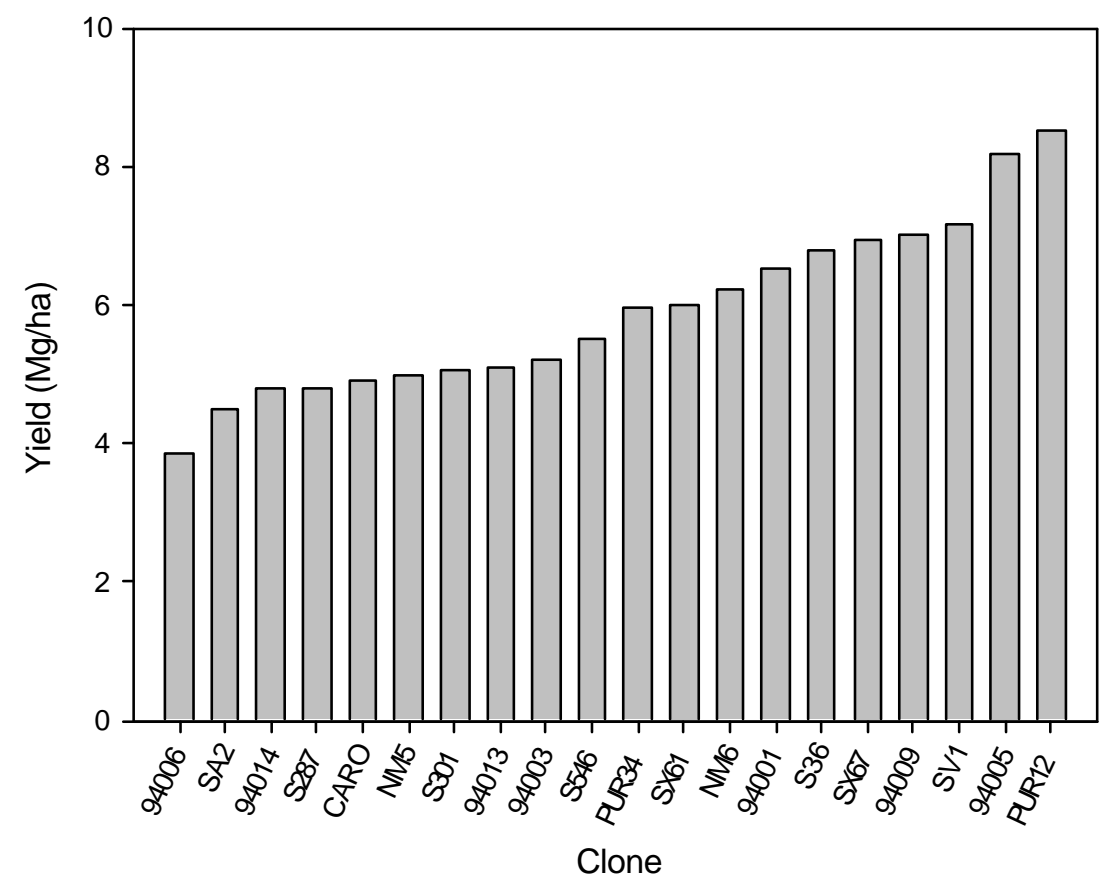

Fig. 2.5. Mean yield of the best 20 willow and Populus (CARO, NM5, NM6) clones at end of establishment year (1997) in Tully, New York. Source: $P$. Tharakan, State University of New York College of Environmental Science and Forestry, Syracuse, New York.

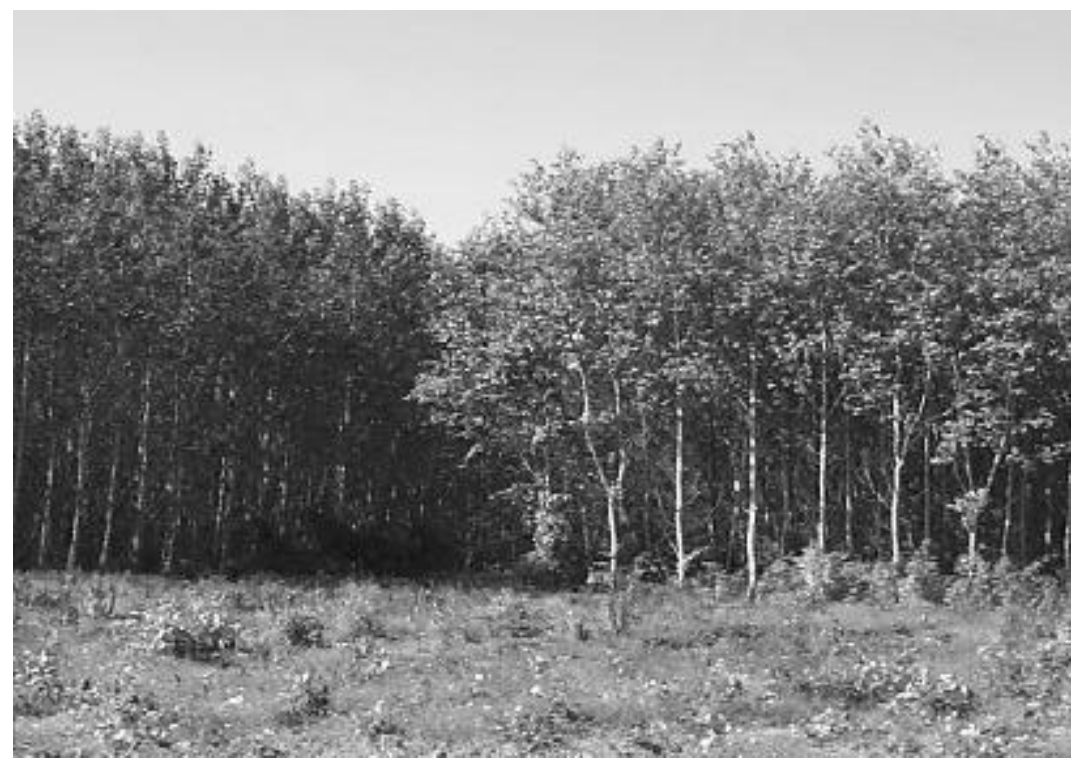

Fig. 2.6. Six-year-old Populus hybrids in the Pacific Northwest. Tree height approximately $20 \mathrm{~m}(65 \mathrm{ft})$. 
plant materials have been transferred to industrial regional trials. At ORNL, researchers are using mathematical modeling and molecular genetics assays to understand the genetic mechanisms of sexual differentiation and wood formation in willow. Using such tools, it may be possible to determine gender early in breeding schemes and to understand wood formation in trees which in turn could have a positive impact on biomass production.

\subsubsection{Herbaceous Crops}

Switchgrass breeding in BFDP includes basic research on the phenology, genetics, and breeding characteristics combined with multiple breeding approaches designed to improve switchgrass productivity as rapidly as practical. Switchgrass breeding programs are located at USDA Agricultural Research Service (ARS), Lincoln, Nebraska; Oklahoma State University (OSU), Stillwater; and University of Georgia, Athens (UGA). Research on tissue culture propagation and genetic transformation is ongoing at the University of Tennessee (UT)

(Fig. 2.7). Recent overviews of the switchgrass reproductive characteristics and breeding programs are provided in Taliaferro et al. ${ }^{59}$ and McLaughlin et al. ${ }^{60}$

Breeding research in BFDP has built upon early work that identified chromosomal and cytological differences between upland and lowland switchgrass cultivars. Hopkins et al. ${ }^{61}$ and Hultquist et al. ${ }^{62,63}$ examined many populations of switchgrass and found that nearly all lowland ecotypes were tetraploid and that upland types were predominately tetraploid and octaploid with some hexaploid types. The extent to which hybridization can occur between switchgrass plants of different ploidy or ecotypes has been investigated by researchers at OSU and USDA/ARS. These studies have documented that self-fertilization in switchgrass is very low, that hybridization potential between plants of different ploidy levels is very low, and that plants of the same ploidy level can usually be intercrossed regardless of ecotype.$^{64,65,66,67}$ The recognition that a reliable, consistent source of switchgrass tissue was needed has led to the development of nurseries maintained by USDA/ARS (Fig. 2.8) and at OSU; currently more than 100 combinations of known and wild accessions of switchgrass at OSU have been characterized for important cytogenetic and agronomic traits.

Recurrent restricted phenotypic selection was initially used in breeding for increased productivity in switchgrass. While genetic gains for improved yield were identified, inadequate seed set and low correlation between biomass yields of plants during the establishment year with those attained by more native plants from year to year led to the development of an alternative approach. ${ }^{60}$ Currently, genotypic recurrent selection is being used to increase biomass yield in breeding populations. This approach focuses on selection based on the performance of the parents' progeny, and although this type of selection takes more time to complete a breeding cycle, genotypic recurrent selection appears to be the best indicator of the breeding value of switchgrass. Thus far, many of the experimental synthetic varieties bred over the past few years at OSU are producing significantly more biomass than standard varieties (Fig. 2.9). ${ }^{59}$ Hybrids of parents identified through genotypic recurrent selection have been found to demonstrate heterosis or "hybrid vigor" for biomass yields. The first-generation hybrid populations of three switchgrass clones tested at OSU have been found to outperform the parents ${ }^{59}$ and standard varieties (C. Taliaferro, OSU, personal communication). Preliminary data for switchgrass hybrids developed in Nebraska indicate that heterosis is exhibited by progeny of some populations and plants from those populations as well (K. P. Vogel, USDA/ARS, personal communication). 


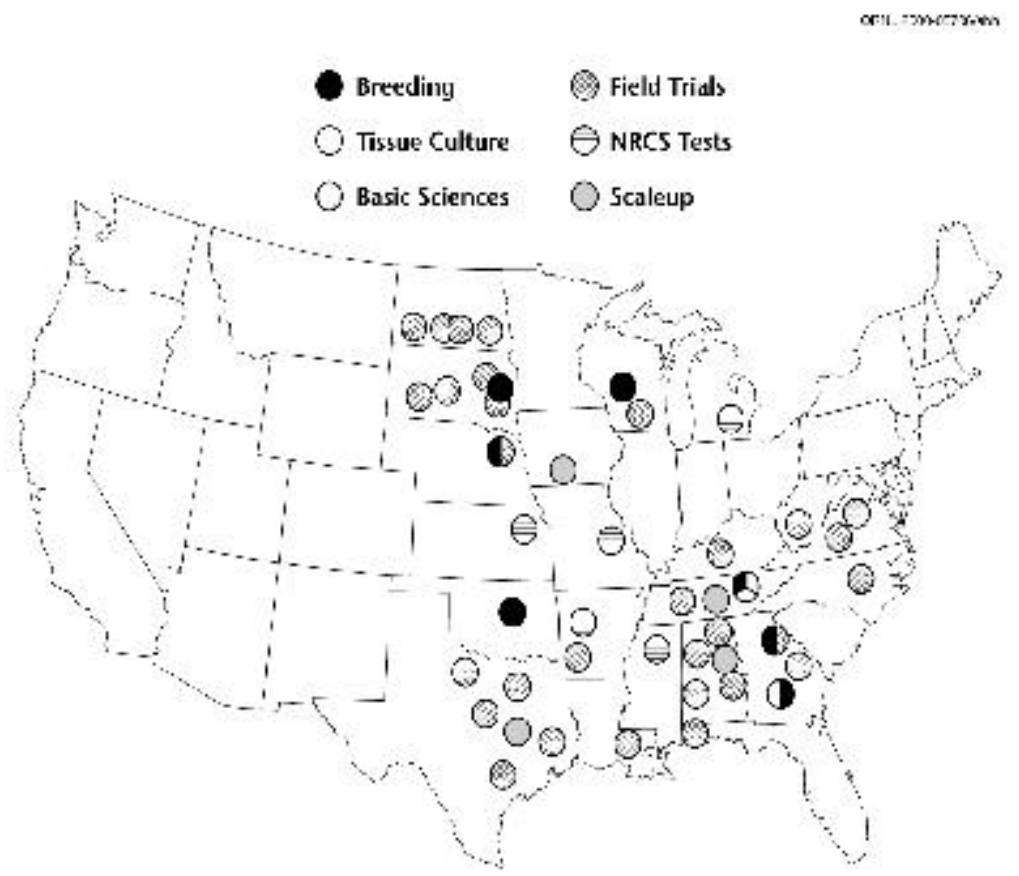

Fig. 2.7. Location of research activities in the herbaceous crop selection and breeding.

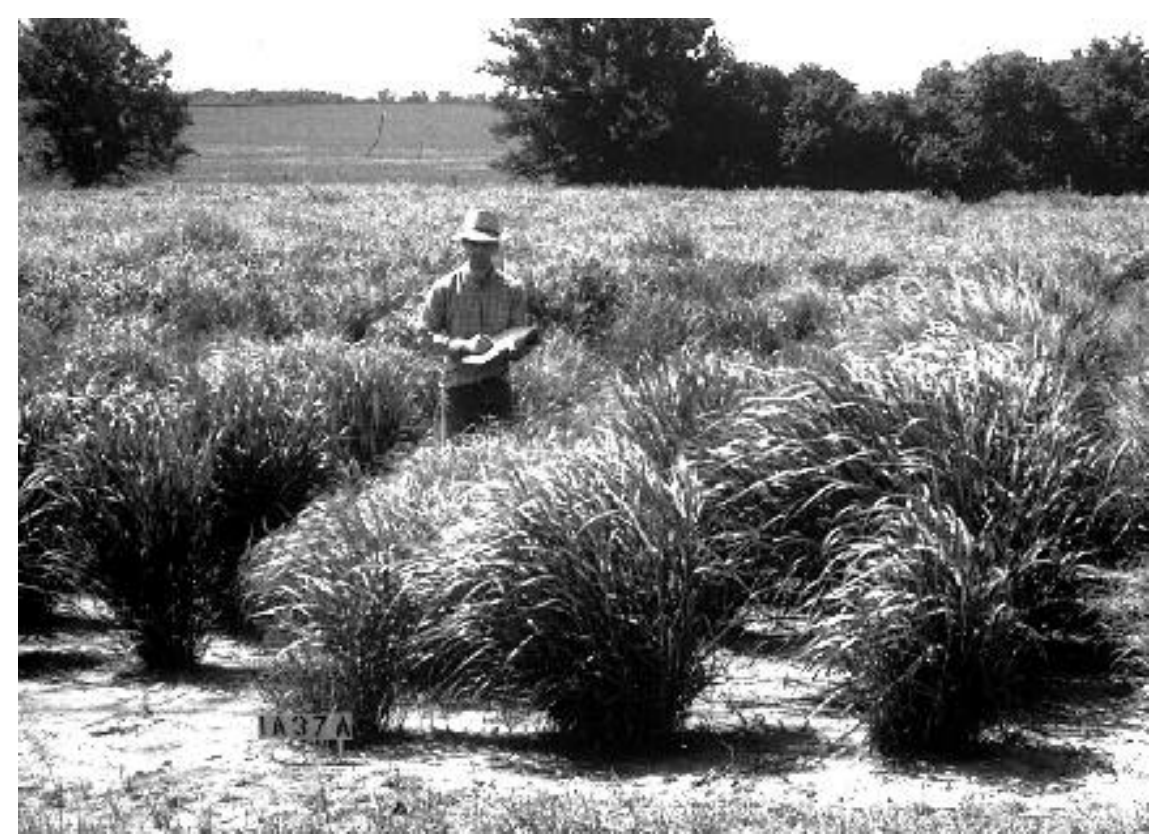

Fig. 2.8. Switchgrass nursery maintained at USDA/ARS. Source: K. Vogel, USDA/ARS. 


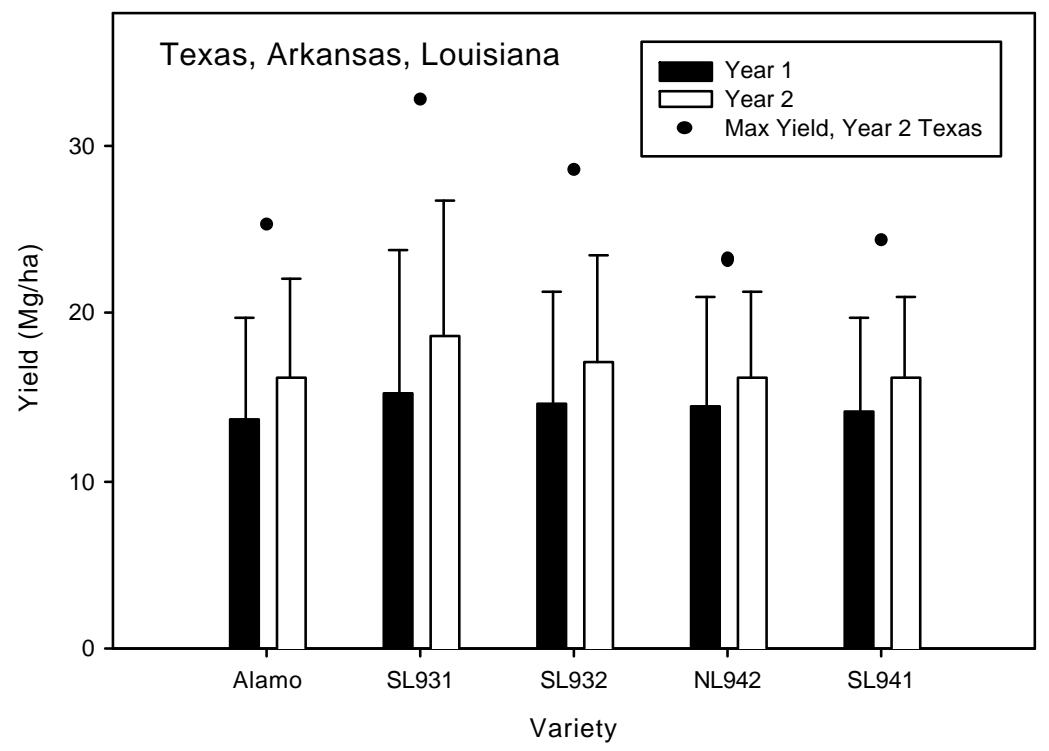

Fig. 2.9. Average yield (error bars $=$ standard deviation) of Alamo and synthetic switchgrass varieties from breeding program at Oklahoma State University (C. Taliaferro) at 5 to 6 sites. Stands established in 1997 (year 1). Sites managed by W. Ocumpaugh, Texas A\&M, include Stephenville, Dallas, and College Station in Texas and Clinton, Louisiana. Site managed by USDA Plant Materials Center is in Booneville, Arkansas. Sites harvested in late summer/early fall and received single application of $\mathrm{N}$ fertilizer. College Station and Dallas locations received supplemental irrigation in 1998.

New molecular tools are being developed to explore the fundamental biology of switchgrass, to improve classical breeding, and to set the stage for potential gains through genetic transformation (if deemed desirable). These tools include development of tissue culture techniques for clonal reproduction of parent plants, molecular fingerprinting, genetic mapping, and linkage of cultures. $^{68,69,70,71,72,73,74}$ These clonal propagation techniques are being used successfully at UT to provide tools to assist classical breeding (Fig. 2.10).

Clonal propagation is also a prerequisite to exploring genetic transformation in switchgrass. In 1999, Richards et al. ${ }^{75}$ successfully transferred a gene that provides tolerance to a herbicide into an Alamo switchgrass genotype. At ORNL, various types of DNA markers are being used to investigate genetic identity among and variability within switchgrass genotypes. To date, the genetic relationships among ten upland and four lowland switchgrass accessions have been identified, ${ }^{76}$ as well as the genetic identities within commercial sources of the lowland 'Alamo' (Table 1). These various tools will be essential if it proves economically and environmentally desirable to tailor crops for specific end uses. 


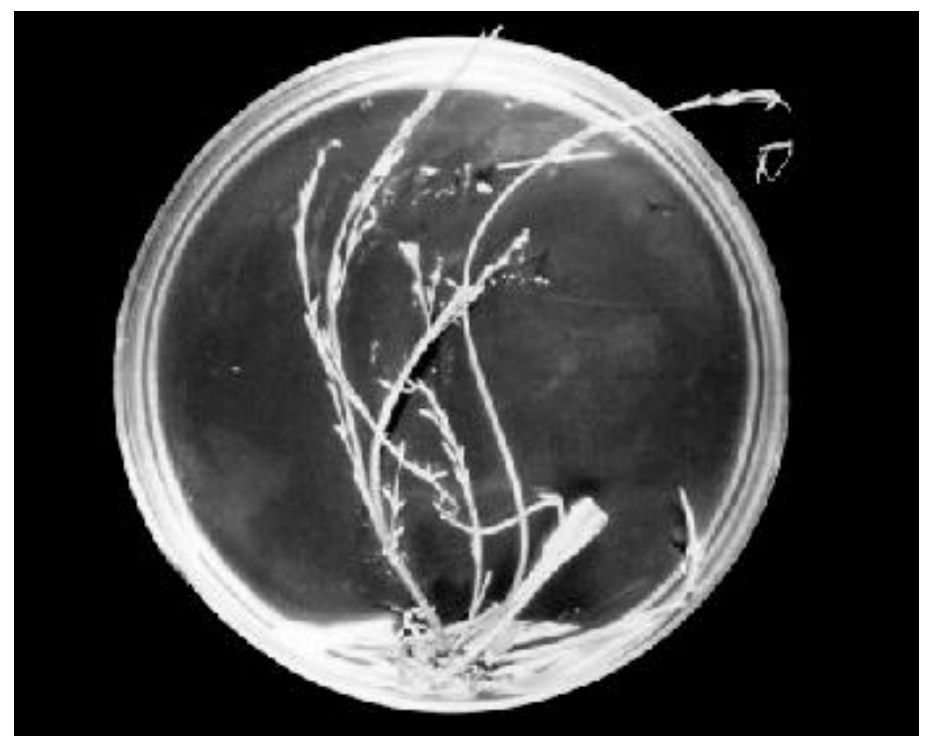

Fig. 2.10. Production of switchgrass inflorescence from node culture. Source: B. Conger, University of Tennessee, Knoxville.

Physiological research in support of breeding efforts has included studies of the physiology of gas exchange in switchgrass leaves. Results to date indicate that while differences in single-leaf physiological attributes, such as photosynthesis and transpiration, are related to growth potential, the way in which they are integrated at the whole-plant level in switchgrass is complex. ${ }^{77} 7879$ Their influence on whole-plant growth is most likely controlled strongly by the seasonal dynamics and plant-to-plant variations in plant and stand-level canopy architecture and allocation patterns that control the distribution of resources between shoots and roots. ${ }^{60}$ Thus, those attributes have not provided useful indicators of whole-plant growth potential to date.

BFDP recognizes that alternative species could have high potential for bioenergy and biobased products. A greater diversity of species would also use a wider range of the land base and would reduce the risks associated with large-scale production of a single crop type. While switchgrass is the first herbaceous species chosen for development as an energy crop, alternative species may (1) be ideal for locations unsuitable to switchgrass (e.g., southern Texas), (2) provide alternatives to producers, (3) obtain higher yields at some locations, or (4) have chemical characteristics that make them desirable for energy conversion or biobased products. Yields of bermudagrass (Cynodon dactylon), bahiagrass (Paspalum notatum), and napiergrass (Pennisetum purpureum) have been evaluated since 1996/1997 at three locations in Georgia. Dry matter yields of napiergrass (Merkron variety) have been consistently greater than those of any other species, including Alamo switchgrass. Winter damage to this species may indicate that its greatest potential lies mainly in the Coastal Plain region of the southeastern United States (J. Bouton, UGA, personal communication).

The potential of legumes (Desmanthus sp.) and giant reed (Arundo donax) as bioenergy crops in southern Texas will be investigated by researchers at Texas A\&M in the upcoming year. Several varieties of sericea lespedeza (Lespedeza cuneata) have been established in Alabama, 
and stands are currently being evaluated for yield, composition, and combustion quality (D. Bransby, AU, personal communication). The effects of cutting height and frequency are also being investigated. Rotation biomass systems using annual crops, such as forage soybean, sunn hemp (Crotalaria juncea), kenaf (Hibiscus cannabinus), ryegrass (Lolium perenne), and tropical alfalfa (Clitoria ternatea), are being investigated at several locations in Alabama. The potential of two promising native grasses, eastern gamma grass (Tripsacum dactyloides) and big bluestem

(Andropogon gerardii), as bioenergy crops are being investigated by the USDA Natural Resources Conservation Service in Mississippi and southern Georgia.

Additional species being evaluated for yield include giant reed and Miscanthus. Two summary reports that review the potential for bamboo and Miscanthus as bioenergy crops were recently published. Bamboo, a group of large woody grasses, is commonly used for fiber and food within Asia and may have potential as a bioenergy or fiber crop for niche markets. ${ }^{80}$ Miscanthus is a tall perennial grass that has been evaluated in Europe over the past 5 to10 years as a new bioenergy crop. The sustained European interest in Miscanthus suggests that this novel energy crop deserves serious investigation as a possible candidate biofuel crop for the United States alongside switchgrass. ${ }^{81}$

Table 1. Similarity (\%) among Alamo seed sources based on Nei’s Unbiased Genetic Distance ${ }^{\mathrm{a}}$ using random amplified polymorphic DNA (RAPD) markers.

The higher the number, the more closely related.

\begin{tabular}{|c|c|c|c|c|c|c|c|c|c|}
\hline & $\begin{array}{c}\text { Alam } \\
\text { o } \\
\text { A }\end{array}$ & $\begin{array}{c}\text { Alamo } \\
\text { B }\end{array}$ & $\begin{array}{c}\text { Alamo } \\
\mathrm{C}\end{array}$ & $\begin{array}{c}\text { Alam } \\
\text { o } \\
\text { D }\end{array}$ & $\begin{array}{c}\text { Alamo } \\
\text { E }\end{array}$ & $\begin{array}{c}\text { Alamo } \\
\text { F }\end{array}$ & $\begin{array}{c}\text { Alam } \\
\text { o } \\
\text { G }\end{array}$ & $\begin{array}{c}\text { Alamo } \\
\mathrm{H}\end{array}$ & $\begin{array}{c}\text { Blackwell } \\
\text { S }\end{array}$ \\
\hline Alamo B & 97.04 & & & & & & & & \\
\hline Alamo C & 96.55 & 99.47 & & & & & & & \\
\hline Alamo D & 95.37 & 99.28 & 99.63 & & & & & & \\
\hline Alamo E & 97.77 & 99.17 & 99.64 & 99.40 & & & & & \\
\hline Alamo G & 96.70 & 98.94 & 99.37 & 99.29 & 99.79 & & & & \\
\hline Alamo $\mathrm{H}$ & 96.52 & 98.98 & 98.89 & 98.90 & 99.02 & 99.46 & & & \\
\hline Alamo S & 95.18 & 96.90 & 96.76 & 95.82 & 95.36 & 95.45 & 95.83 & & \\
\hline Blackwell S & 95.28 & 93.64 & 94.35 & 93.28 & 95.76 & 94.61 & 93.82 & 90.21 & \\
\hline Blackwell + & 90.26 & 91.46 & 89.78 & 90.76 & 88.44 & 87.96 & 90.23 & 87.65 & 86.10 \\
\hline
\end{tabular}

${ }^{a}$ Nei, M. 1978. Estimation of average heterozygosity and genetic distance from a small number of individuals. Genetics 89:583-590.

Source: L. Gunter, Oak Ridge National Laboratory. 


\section{CROP MANAGEMENT RESEARCH}

Crop management research has been an integral component of BFDP since its inception. Issues related to selection of planting stock, spacing, rotation length, fertilization, irrigation, and weed and pest control clearly affect yield and cost.

\subsection{WOODY CROPS}

Early recommendations for silviculture practices were developed for a variety of woody crops and focused on coppice systems. ${ }^{6}$ Knowledge gained in the late 1980 s and early 1990s ${ }^{5-9}$, ${ }^{27,37}$ led to redirection toward 6- to 10-year rotations, single-stem management for Populus and continuation of a 3- to 4-year rotation, coppice harvest for willow. This change was based primarily on the realization that clonal selection in poplar could result in yield advances so rapidly that it would be more cost-effective to replant after 6 to 10 years than to coppice. The same is not true in coppice willow management where high planting densities result in very high planting costs. Current recommendations are to establish SRWC plantations at 1200-1400 stems/ha (490-560 stems/ac) grown under 6- to 10 -year rotations. ${ }^{82,}{ }^{83}$ Higher density plantings were investigated and shown to be less desirable for Populus. ${ }^{84,85}$ However, for hybrid willow, twinrow, high-density plantings grown under 2- to 3-year rotations have been successful and produced $15.7 \mathrm{Mg} / \mathrm{ha} / \mathrm{yr}$ (7 dry tons/acre/year) in research plots. ${ }^{86,}{ }^{87}$ In terms of site selection and site limitations, 'good' idle or excess agricultural land is recommended, although prediction of site quality for SRWC production is still not an exact science. ${ }^{88}$

Although many silviculture issues, such as spacing and rotation length for Populus and willow, have essentially been resolved, management issues, such as rapid increase of preferred clones, fertilization, irrigation, and disease and insect control, are region- or site-specific and thus are not resolved for all locations. These issues are an important component of site-specific operational studies.

Fertilization for SRWC grown for 6- to 10-year is currently recommended on an "as-needed" basis beginning about midrotation (age 3 to 4 years). Coppice willow stands are normally fertilized in the second year of growth. Nitrogen fertilization at time of planting is not recommended for either species, because weed growth that competes with seedling growth would be stimulated. Efforts are under way to develop plant-based fertilizer prescriptions, such as using the level of nitrogen in leaves to indicate "need." However, current methods fall short of optimizing fertilizer use efficiency, presumably because of lack of a full understanding of the constraints caused by water and nutrient availability and interactions. As mentioned in Section 2, a co-operative study with International Paper Company on industry land in South Carolina has been investigating factors affecting growth limitations. This study has involved looking at the impacts of fertilization and irrigation on tissue-specific physiological parameters, such as photosynthetic rates, respiration, and leaf $\mathrm{N}$ content for sycamore, sweetgum, and several clones of cottonwood. Results are still being analyzed and modeled. In 2000, a cooperative group including the USDA-FS, ORNL, and several private companies will initiate a new set of studies at DOE's Savannah River Site to investigate the response of cottonwood and loblolly pine to nutrient and water manipulations. In both cases, the goal is to understand the differing physiological and genetic mechanisms of carbon

gain and allocation in different species and clones and to develop information on how to manage 
the sites to optimize growth of the trees. The second study will use information from the first study to improve study design and refine the questions being asked.
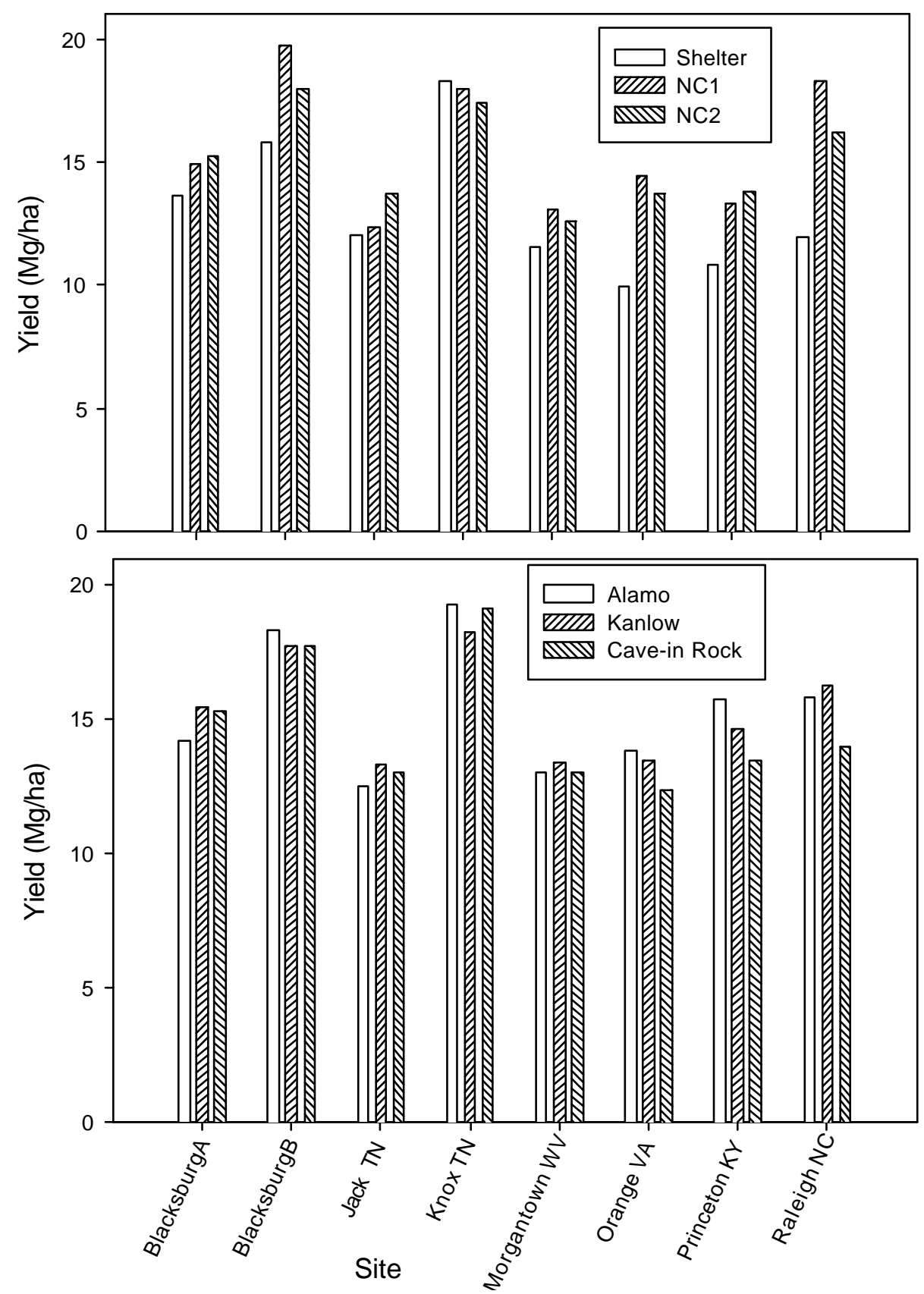

Fig. 3.1. Average switchgrass yields for 1992-1999 at sites in the Virginia Polytechnic Institute and State University program. Stands established in 1992 with exception of Princeton which was established in 1993. Stands harvested twice per year. Source: D. Parrish, Virginia Polytechnic Institute and State University. 
Drought stress is a major limitation to tree growth, but irrigation is a significant cost factor and is not environmentally desirable in many areas of the country. Irrigation is not a major emphasis of BFDP - except to help in understanding nutrient and water interactions. The best solution to overcoming drought stress in trees planted as dedicated crops for bioenergy is believed to be selection for trees with superior genetic characteristics. Therefore, research has been conducted for several years on hybrid poplar clones in commercial plantations in the Northwest and Southeast in order to understand the mechanisms underlying genetic differences in drought resistance.

Superior clones have been identified, and this information has been provided to industrial breeders.

Weed control is the most important management activity needed to obtain high survival of the stand (preferably greater than 95\%) and to establish the foundation for rapid growth throughout the rotation. Research by many investigators during the 1980s clearly demonstrated the importance of beginning site preparation at least one year in advance of planting and of effective weed control in the first growing season. Operational plantings by BFDP collaborators and by private industry identified a suite of herbicides and tillage methods that were effective in weed control but often left considerable bare ground in young plantings. Weed control is less of an issue in coppice willow plantings since the dense growth quickly shades out the weeds. For poplars and other single-stem tree production, the recent strategy has been to develop methods of controlling the weeds just within the tree rows while allowing weeds or planted annuals to occupy the centers of the rows between the trees. Several BFDP investigators have and continue to collaborate with private industry in developing new herbicides and combinations of herbicides that facilitate this approach. The new herbicides Milestone, developed by DuPont, and Scepter, made by American Cyanimid, show great promise for use in this way.

Insects and disease have the potential to seriously hinder the development of woody species as energy crops. For example, the most serious insect or disease problem facing SRWC Populus planting in the United States today is Septoria stem canker (Septoria musvia). Planting resistant or tolerant clones is the only control measure available to SRWC farm managers. In regions where this disease is causing economic damage, there are relatively few resistant clones available for planting. Research at ISU and at the USDA North Central Research Station is focused on developing new cottonwood clones that are resistant to the cottonwood leaf beetle, Septoria stem canker, and Melampsora leaf rust. Developing genetic resistance to pest problems means higher biomass yield and less pesticide use. In addition to developing resistance though breeding, it is important to have an understanding of the biological aspects of both the pest and woody crop. For

example, research at Washington State University is investigating the mechanisms of disease resistance and the impacts of disease on the growth and physiology of Populus. The USDA North Central Research Station is using tissue-culture-derived clones to characterize disease resistance and assess the level of genetic variation in Septoria.$^{89,90,91}$ An understanding of the distribution and genetic variation of pathogens is needed to effectively develop screening systems that can test poplars for disease resistance.

\subsection{HERBACEOUS CROPS}

Crop management research for switchgrass focuses on practices or conditions that constrain the use of switchgrass for energy. These constraints may be related to planting (i.e., row spacing); establishment (i.e., successful planting and growth of a plot); use of chemicals for fertilizer; weed or pest control; soil quality; or harvest regime. Through a network of 18 field sites established in 1992 (Fig. 2.7), we are evaluating the yields of a total of 9 switchgrass cultivars under various 


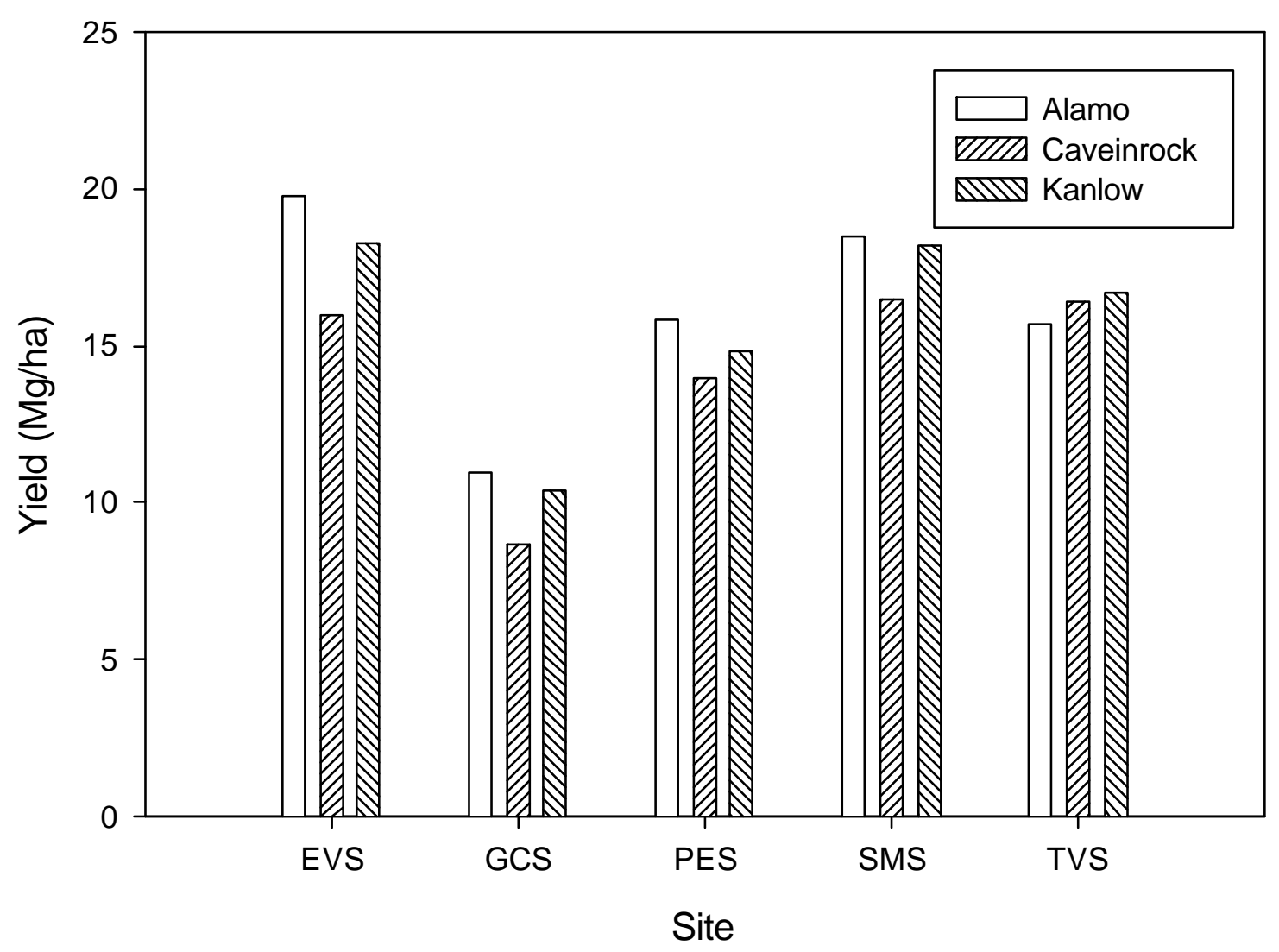

Fig. 3.2. Average switchgrass yields for 1993-1999 at five Alabama sites in the Auburn University program. Stands established in 1992 and harvested twice per year. N-fertilizer applied annually. EVS = E.V. Smith Research Center, Milstead; GCS = Gulf Coast Substation, Fairhope; PES = Piedmont Substation, Camp Hill; SMS = Sand Mountain Substation, Crossville; TVS = Tennessee Valley Substation, Belle Mina. Source: D. Bransby, Auburn University

management strategies. The results to-date of the field trails established by VPI and Auburn are shown in Figs. 3.1 and 3.2. Across all three regional trials, average yields of the best cultivar at each location were approximately 16 dry $\mathrm{Mg} / \mathrm{ha}$ ( 7 dry tons/acre), while maximum yields at any plot within each of the 3 regions were typically $\$ 20 \mathrm{Mg} / \mathrm{ha} .{ }^{60}$

Comparisons of yield performance among cultivars indicate that the most promising cultivars for bioenergy production are 'Alamo' for the deep South, ${ }^{92}$ 'Kanlow' for mid latitudes, and 'Cavein-Rock' for the central and northern states. ${ }^{60}$ Management practices that affect yield and stand longevity are being evaluated at our regional centers located at Texas A\&M University, Auburn University, University of Georgia Athens, and USDA ARS/University of Nebraska and include (1) establishment practices; (2) frequency of harvesting (1-cut vs 2-cut systems); (3) timing of harvest and how timing of the second cut affects ash content; ${ }^{33}$ (4) effects of cutting height on stand longevity, yield, and composition; and (5) irrigation. 
Establishment issues, such as seed dormancy, seed scale-up, and the use of herbicides and/or insecticides, are important because of their potential impacts on cost. Stand failures as a result of poor seed quality, weed competition, and seedling physiology will have major implications on the cost of switchgrass biomass. Successful stand establishment practices have been developed for the Southeast, including methods to break seed dormancy, ${ }^{94,}{ }^{95}$ recommendations for fertilizer $(\mathrm{N}, \mathrm{P}$, and K) application, and herbicide regimes. ${ }^{96,97}$ A summary of the characteristics and uses of herbicides in the production of herbaceous perennial species grown for bioenergy is given in Buhler et al. ${ }^{98}$ Although a great deal of progress on establishment has been accomplished, research efforts are continuing to optimize establishment in all regions. Research at VPI has shown some advantage to using insecticides at planting (D. Parrish, personal communication), whereas at AU and Texas A\&M insecticides applied during planting did not improve the yield (D. Bransby and W. Ocumpaugh, personal communications). Research has been conducted by the USDA/ARS to determine the effectiveness of new herbicides in aiding switchgrass establishment at several sites in eastern Nebraska. Pre-emergent applications of atrazine appear to improve establishment and a new herbicide "Plateau" was labeled in 1996 for use on non-crop land for establishing native warm-season grasses. It is hoped that it will be labeled for switchgrass establishment and available for use on all grasslands soon (K. Vogel, USDA/ARS, personal communication).

Planting methods that are being investigated include planting switchgrass into the stubble remaining from a winter annual and comparisons of different types of planters. At AU, planting into winter annual stubble had little effect on switchgrass yields in the establishment year compared with conventionally prepared seed beds (D. Bransby, AU, personal communication). The type of planter used for switchgrass establishment may improve establishment and yield. In the first year of harvest, switchgrass yields were higher from plots planted with cone and Brillion planters compared with a 'Flex-71' conventional 4-row planter and a precision pneumatic planter (D. Bransby, AU, personal communication).

The consequences of spacing during planting have been investigated by AU and Texas A\&M. At AU, wide row spacing provided equal or better yields than solid stands (David Bransby, AU, personal communication) whereas in Texas, Alamo did not respond to differences in row spacing (W. Ocumpaugh, Texas A\&M University, personal communication). The difference in responses is likely due to soil moisture.

Significant progress has been made on understanding the best harvest regime for specific regions. The two basic harvests regimes investigated are a single cut in the last third of the growing season versus a 2-cut system with the first cut typically at the date of formation of seed heads, around July. Yield data from three years of field trials emphasize the regional specificity of optimum cutting practices. Highest yields have typically occurred with the 2-cut system at VPI (Fig. 3.3) and AU study sites, ${ }^{60}$ while in Texas, where drought has been a frequent problem, the 1cut system has been superior. ${ }^{99}$

The effect of fertilizer (nitrogen and phosphorus) on switchgrass yield and the associated costs of fertilizer, both economical and ecological, are important considerations in developing herbaceous crops for bioenergy. The standard practice for fertilizer is to apply \#50 kg/ha (44 lbs/ac) of N during the first year after switchgrass emergence, followed by $80-100 \mathrm{~kg} / \mathrm{ha} / \mathrm{yr}$ (70-90 lb/ac/yr) thereafter. ${ }^{100}$ Current research has included these and much higher rates in the search for an optimum balance between costs and yield. To date, positive yield responses have been found up to and including $224 \mathrm{~kg} \mathrm{~N} / \mathrm{ha} /$ year ( $200 \mathrm{lb} / \mathrm{ac} / \mathrm{yr}$ ), however, we suspect that long-term yield stability and economics will be favored by lower annual or even longer interval applications of $\mathrm{N}$, particularly where a single annual harvest is used. ${ }^{60}$ At the Texas, Virginia, Tennessee, Kentucky, North Carolina, and West Virginia research sites, Alamo switchgrass yields have not been 

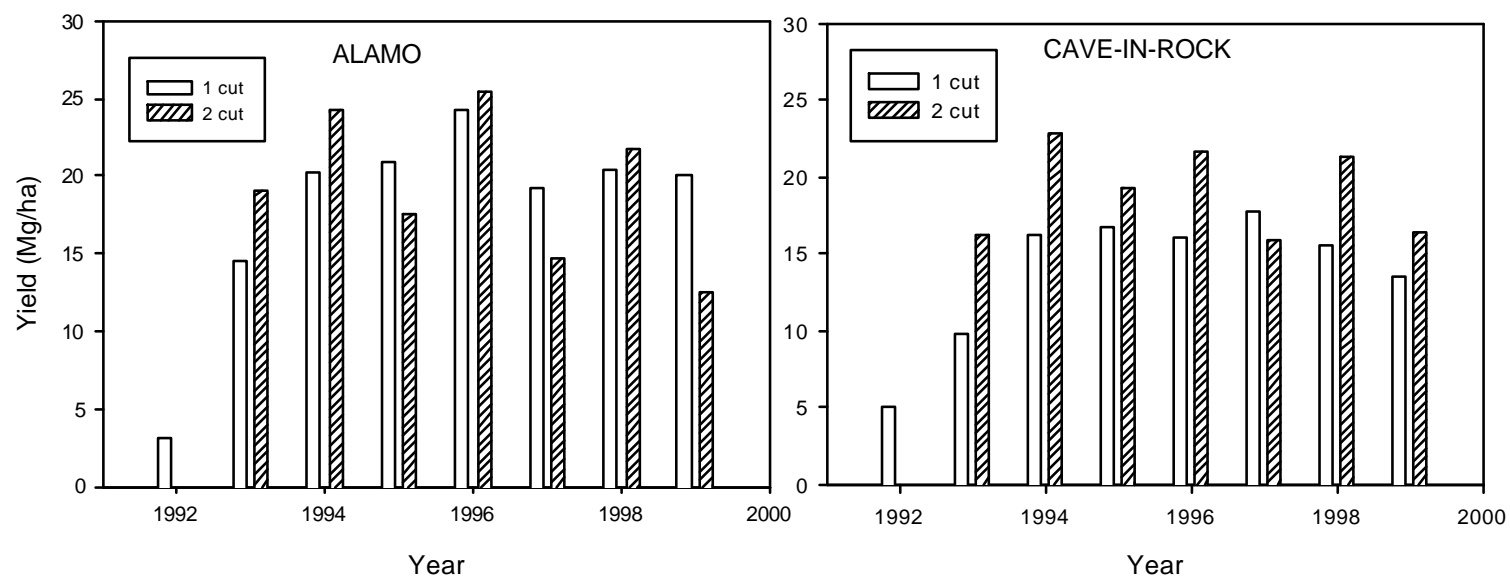

Fig. 3.3. Average switchgrass yield in 1- and 2-cut systems at Knoxville, Tennessee, site. Stands established in 1992. Source: D. Parrish, Virginia Polytechnic Institute and State University.

improved by the addition of phosphorus (W. Ocumpaugh, Texas A\&M University, and D. Parrish, VPI, personal communications).

\subsection{ENVIRONMENTAL ASSESSMENT AND MONITORING}

Environmental research became a separate task of BFDP in 1992 when issues were raised about whether biomass crop production would be both environmentally sustainable and even provide environmental benefits. Our objective has been to develop the quantitative data to identify the environmental benefits and risks associated with biomass crop establishment, management, harvest and use. These data address soil quality, water quality, and biodiversity issues. In addition, we are identifying management practices that can be incorporated to ensure environmentally sustainable production of both woody and herbaceous crops. A preliminary summary of BFDPfunded research on the environmental aspects of bioenergy crop production from 1992 to 1996 is provided by Tolbert and Wright. ${ }^{101}$

\subsubsection{Water Quality}

Issues of water quality that could affect biomass crop production are increasingly becoming a concern because of the potential for transport of herbicides and nutrients into surface water and groundwater. The BFDP has been aggressively working to quantify the changes that occur in surface water and groundwater quality and quantity with conversion of agricultural croplands to SRWC and/or switchgrass. Increasingly, the BFDP has been collaborating with the larger biomass community, including the Northeast Regional Biomass Program, utilities, researchers, and other groups, to evaluate how energy crops can play a roll in organic nutrient management and be managed to maximize nutrient use efficiency. These efforts have included preliminary studies to identify options to utilize animal and other waste resources for nutrients while reducing the effects of animal waste on water quality. ${ }^{102,103}$

In the Southeast, small-scale studies have been conducted since 1995 at three locations (Alabama, western Tennessee, and Mississippi) to evaluate erosion, surface water quality and 
quantity, and subsurface movement of water and nutrients from woody, herbaceous, and agricultural crops. ${ }^{104}$ For the biomass crops, the greatest erosion losses occurred in the spring following establishment. As biomass crops more fully occupied the sites and soil cover increased, quantities of runoff, sediment, and nutrient losses declined relative to the agricultural crops (Fig. 3.4). ${ }^{105,106}$ 107, 108 Nutrient losses were closely linked to fertilizer application and the timing and intensity of subsequent rainfall.

Cooperative studies located in South Carolina with a forest products industry, North Carolina State University, and the USDA/FS have also addressed water quality issues associated with fertigation (a combination of fertilizer and irrigation) and large-scale biomass crop production. A watershed study [20-40 ha (50-100 ac) and 800 ha (1970 ac) comparisons] is evaluating the effects of water level manipulation on water quality and quantity, soil quality, and SRWC productivity. Nutrient and hydrologic models are being parameterized using the experimental data to allow us to project to a wider variety of sites with different nutrient and management options. Fertigation comparisons for hybrid cottonwood, sycamore, and sweetgum were initiated with industry to identify the potential to maximize productivity. The higher fertigation resulted in high nitrate concentrations in the subsurface waters in the first and second years after planting, but in subsequent years, there has been little nutrient movement in soil water beyond the 1-m depth (D. Todd, ORNL, personal communication).

In the north-central region, researchers with the University of Minnesota have compared the impact of short-rotation hybrid poplar plantations and traditional natural forest on regional groundwater quality and quantity. ${ }^{109,110}$ Soil water samples have shown different temporal patterns of nitrogen and phosphorous export; however there were no significant differences in export related to crop type. Direct comparisons of nutrient and herbicide movement during establishment and early management of hybrid poplar, switchgrass, and wheat have shown that over the first three years of production no subsurface movement of herbicides applied to the crops has occurred (Ken Brooks, University of Minnesota, personal communication).

\subsubsection{Soil Quality and Carbon Storage}

An integral component of environmental studies of both herbaceous and woody crops includes quantifying the changes that occur in soil quality and soil carbon storage across a range of different management practices, soil types, and climates. Much of the early research quantifying changes in soil carbon was conducted on switchgrass plantings in the Southeast.

Soil carbon sequestration and soil quality under switchgrass plantings is currently being investigated in field plots located in Virginia, West Virginia, Tennessee, Georgia, Oklahoma, Texas, Arkansas, and Louisiana. In the near future, research will be initiated by the USDA to evaluate changes in soil quality and soil carbon levels in the northern Great Plains region. Early indications are that some soil improvement may be occurring in areas planted with switchgrass. ${ }^{111,112}$ For example, researchers have found that switchgrass roots will penetrate to $60-90 \mathrm{~cm}$ and contribute to increased soil C (D. Parrish, VPI, personal communication). In Alabama, improvements in soil quality have been demonstrated by increased yields of conventional agricultural crops (corn and soybean) that were planted after switchgrass in a crop rotation (D. Bransby, AU, personal communication). Similar plantings of cotton following cottonwood trees in Mississippi have also demonstrated the value of biomass crops for soil quality and subsequent crop yields. BFDP has also funded studies to quantify the amount and distribution of coarse roots and soil organic carbon inventories beneath switchgrass and other types of plant cover at four sites in the southeastern United States. Garten and Wullshleger ${ }^{113,114}$ found that there was significantly 


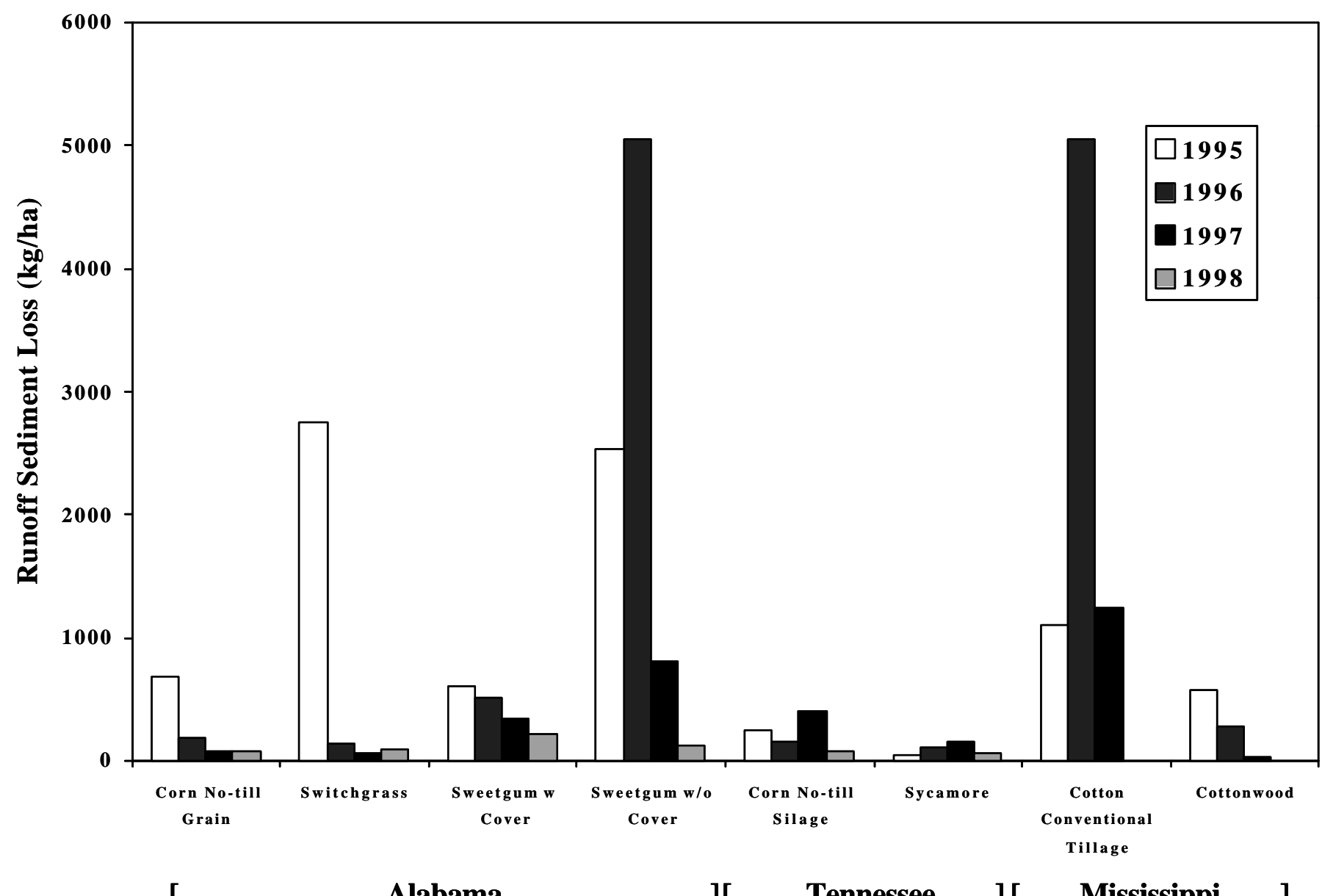

Fig. 3.4. Comparisons of sediment losses from biomass crops and agricultural crops show that losses from biomass crops particularly when grown with a cover crop and from no-till agricultural crop production were much lower that from sites maintained weed free. 
more coarse root $\mathrm{C}$ under switchgrass and forest cover than under tall fescue, corn, or native pastures, but that inventories of soil organic carbon under switchgrass were not different from other plant covers. Using soil organic carbon measurements, they developed a two-compartment model that predicts $\mathrm{C}$ accumulation and turnover in particulate organic matter and mineralassociated organic matter. At the Knoxville, Tennessee, location, they predict a $12 \%$ increase in soil organic carbon inventory over a 10-year period following switchgrass establishment. In Ohio, Lal et al. evaluated soil quality and soil carbon of mined lands after reclamation to pasture and forest. The reclaimed mine lands that had top soil added had increased soil $\mathrm{C}$ storage when compared with long-term pasture and natural forests. Even after 25 years, the soil C level continued to increase in forestland, whereas pastureland accumulation had leveled off (R. Lal, Ohio State University, personal communication).

Soil carbon sequestration and soil quality under woody and herbaceous crops in comparison with agricultural crops is being investigated in the north-central and southeastern United States. At the Mississippi site, carbon increases were documented primarily in the shallow soil $(0-10 \mathrm{~cm})$ under cottonwood but not under cotton production. ${ }^{15}$ At the Alabama site, carbon increases under sweetgum trees with a cover crop, switchgrass, and no-till corn have been documented, whereas carbon losses occurred with production of sweetgum without a cover $\operatorname{crop}^{116}$ (Fig. 3.5). At the Tennessee site, soil carbon has increased under sycamore and no-till corn. ${ }^{115}$ In the north-central region, comparisons of soil carbon under hybrid poplar plantings, agricultural crops, and farm woodlands are inconclusive. Increases in carbon storage were identified on a number of the plantings, but on others, the changes were negligible. The researchers believe that the cooler northern temperatures and the higher existing soil carbon make the changes harder to detect without significantly increasing the number of samples collected (Jud Isebrands, U.S. Forest Service, personal communication). This observation is in contrast to the significant changes in soil quality and soil carbon that are being seen on the southeastern sites where (1) plow pans that restrict root and water penetration are widespread; (2) rainfall, erosion, and summer temperatures are higher; (3) soil organic matter losses have historically been greater; and (4) the potential to increase organic matter and carbon sequestration in the soil is greater.

Recently, BFDP has begun to investigate, in cooperation with USDA/ARS, the environmental implications of using agricultural residue, particularly corn stover, for energy production. Corn stover is a source of soil cover that reduces erosion and a source of organic matter that can maintain or enhance soil quality. Questions about harvesting corn stover for energy production (i.e., conversion to ethanol) center on identifying the effects of removal on erosion, soil structure, and stability and soil sustainability (i.e., whether significant decreases in soil organic matter and carbon would occur with stover harvesting). This research will be part of an effort to identify stover availability and harvest potential while maintaining soil cover, soil stability, and soil quality.

\subsubsection{Biodiversity}

The role of energy crops in enhancing biodiversity has been an area of active research since 1992. Early surveys to determine the use of biomass crops by wildlife were in response to concerns raised by public and environmental groups. Surveys initiated in 1992 across a variety of regions focused primarily on identifying breeding bird use of biomass crops (Fig. 3.6). In 1992 and 1993, intensive surveys of existing experimental and industrial planting of switchgrass and hybrid poplars in the United States and Canada were conducted by Audubon researchers. ${ }^{117,} 118$ In 1994, that work was expanded to monitor established 4- to 6-year-old plantings of hybrid poplar in 


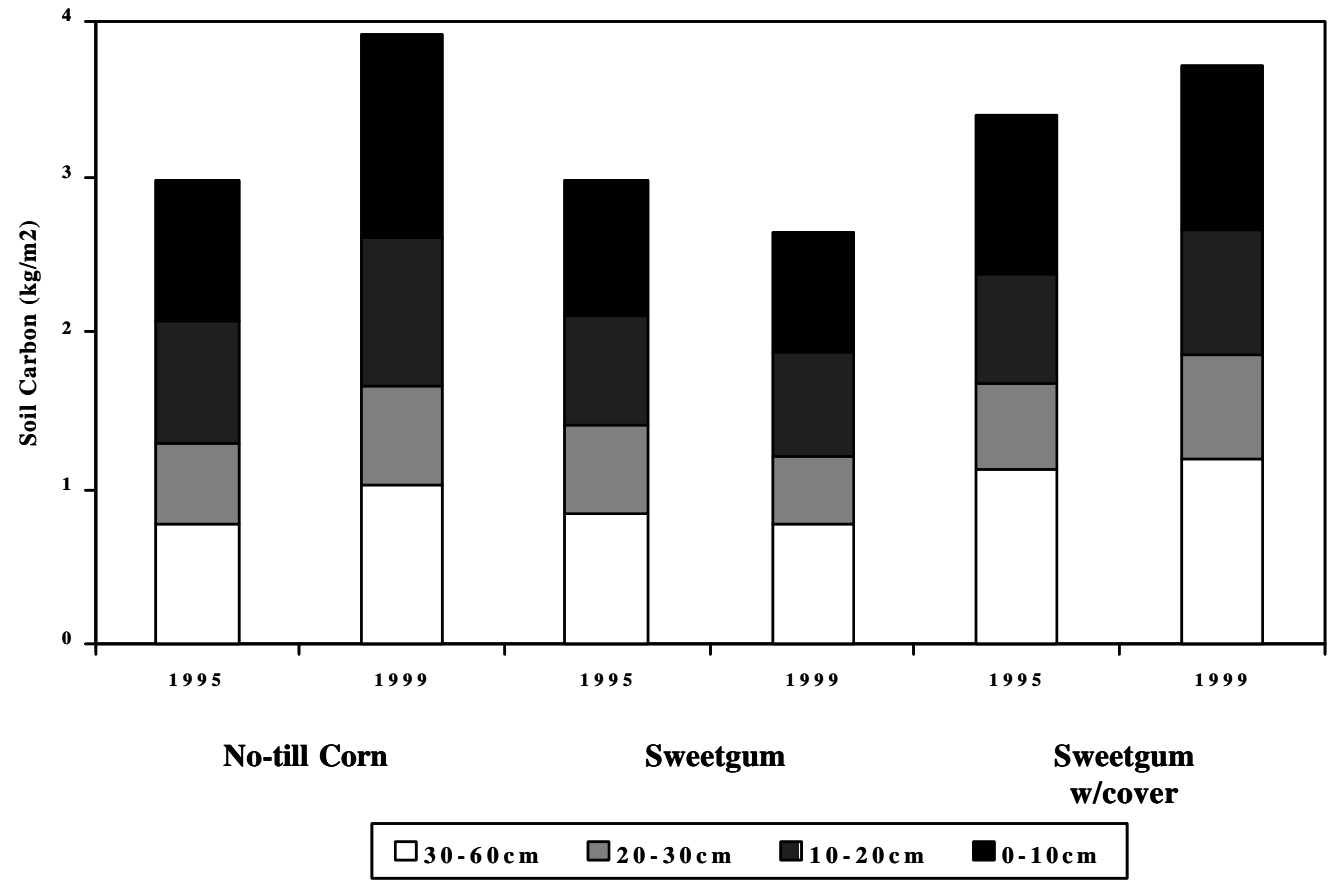

Fig. 3.5. Soil carbon increased across all depth increments $(0-60 \mathrm{~cm})$ with conversion of traditionally cultivated agricultural land to no-till corn and sweetgum grown with a 60-cm-wide fescue cover crop established midway between rows. Sweetgum established without a cover crop and maintained weed free lost soil carbon at all depths within the upper $60 \mathrm{~cm}$ across five years of growth.

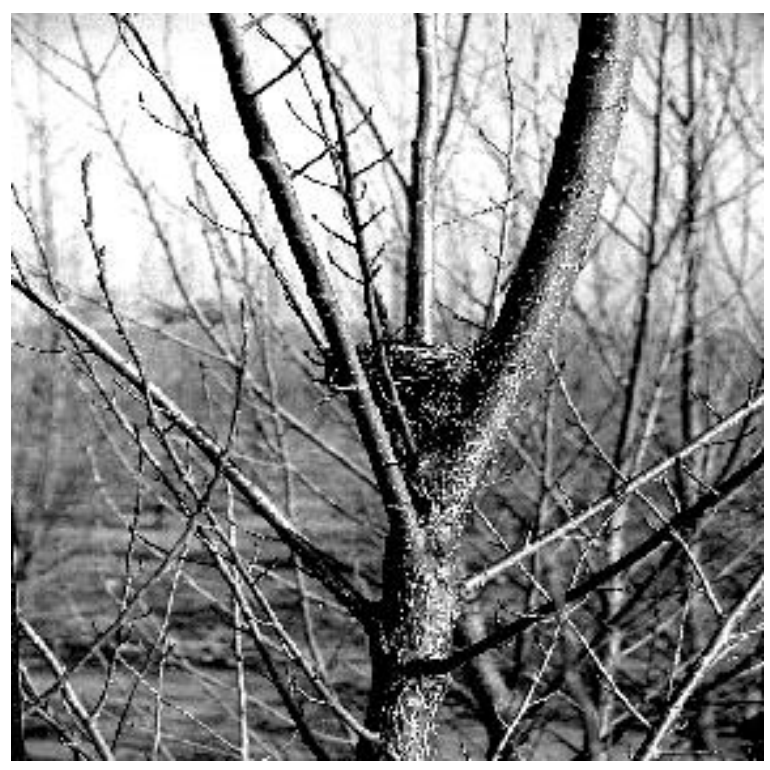

Fig. 3.6. Bird nest in hybrid poplar planting located near Alexandria, Minnesota. 
the prairie transition area of Minnesota and in 1996 to newly established scale-up plantings of hybrid poplar in the same area.

Christian et al. ${ }^{119}, 120,121,122$ found that established hybrid poplar plantings were used more extensively by birds and small mammals than common row crops but less extensively than natural mixed forests. More complex patches of vegetation within plantings, resulting from clonal failure or less frequent mowing, were associated with increases in small mammal and bird abundance and diversity. In the wintertime, hybrid poplar plantings were used by deer and medium-sized mammals much like openland habitats; however, medium-sized mammals typically associated with forests (e.g., snowshoe hares, white-tailed jackrabbits) made little use of poplars. The wide-ranging mammal species neither avoided nor selected hybrid poplar plantings. ${ }^{123}$

In other regions, the use of bioenergy crop plantings by birds has been compared with alternative habitats. In Iowa, Audubon researchers found significant use of switchgrass by several prairie specialist birds, such as sedge wrens, dickcissels, and eastern meadowlarks. However, not all species (e.g., bobolinks) in the surrounding landscape used the switchgrass plantings but preferred nearby prairie-type habitat (J. Beyea, National Audubon Society, personal communication). In the Southeast, use of forest product industry-managed sweetgum, sycamore, and pine plantings by breeding birds was compared with naturally regenerating hardwood forests. ${ }^{124}$ These areas provided the opportunity to study plantings that spanned the range of ages and sizes that could occur across a mixed landscape in support of a biomass industry. Bird community structure and diversity in sweetgum and sycamore plantations were comparable to similar aged hardwood forests. Use of the younger plantings was similar to use of early successional habitat of hardwood forests, both of which would have abundant shrub and weed cover and open canopies. The diversity and abundance of breeding bird use of the young woody crop and pine crop plantings was similar. With tree crop maturity, the bird diversity in the pines dropped to only a few species, while the bird diversity in the woody crops increased and was similar to that in natural forests.

As is true for changes in soil and water quality, the effects of energy crop production on wildlife communities depend heavily on how the stands and acreages of biomass crops are managed both on individual plantings and across entire landscapes. The potential for benefits and mechanisms/production methods to minimize risks will depend upon the soil types, locations, and the types of land covers converted to biomass crop production. The environmental studies to date provide some of the site and field data that can be used to help identify the role biomass crops can play in providing wildlife and soil and water-quality benefits and methods to minimize risks. These data will have to be verified by more extensive sampling across a wider range of locations and within landscape contexts to accurately answer concerns about the environmental sustainability of dedicated biomass crop production. 


\section{OPERATIONAL RESEARCH}

Operational R\&D is conducted in commercial or in pre-commercial systems established in partnership with the private sector. It involves the collection of data to understand and model existing systems and the development of improved systems and equipment with the goal of reducing the cost of the final commercial product (e.g., electricity, ethanol, chemicals, or other bioproducts). Objectives of the R\&D involve demonstrating and improving the reliability and quality of biomass feedstocks, improving overall system efficiency, and reducing costs of feedstock supplies. Supply logistics and crop production operations are addressed as separate (but interactive) operational research elements within the BFDP. The industry-supported SRWC Operations Working Group has also evolved into an important vehicle for sharing operational information between different regions of the country.

\subsection{CROP PRODUCTION OPERATIONAL RESEARCH}

Crop production operational research seeks to promote innovation, cost-reduction, and sustainable approaches in all aspects of crop production, including nursery or seed production operations, site preparation, planting, maintenance, production, and harvest.

BFDP has been engaged in some level of crop production operational research since the mid1980s. However, most studies initiated during this time did not last more than 1 to 3 years because of decreases in program funding, changes in private sector priorities, and difficulty in successful establishment of those plantations (mostly as a result of drought conditions). Although very few results were published, the data reside in BFDP files and in annual project reports.

One of the more successful BFDP-funded "crop operational research" projects from the late 1980s was the establishment of the North Central Hybrid Poplar Regional Planting. In 1987 and 1988, 10-acre plantings of hybrid poplar, each containing 10 different clones, were established across a 4-state region in the north central United States. The work was cooperatively supported by the North Central Forestry Research Station (USDA), BFDP, the Electric Power Research Institute (EPRI) and a private sector partner (Energy Performance Systems, Inc). Approximately 130 acres were successfully established and maintained. The plantings provided information on clonal performance, establishment, and weed control methods that were utilized for operational hybrid poplar plantings established in the mid-1990s in Minnesota. ${ }^{125}$

In the late 1980s and early 1990s several fiber companies in the Pacific Northwest United States established thousands of acres of commercial plantings of hybrid poplar for fiber production (Fig. 4.1). BFDP-funded researchers at the University of Washington and Washington State University were relied upon heavily by those companies for their expertise and knowledge about hybrid poplar clonal performance and crop management techniques. No formal collaborations were established at the time for collecting operational data because of proprietary interests of the companies. However in more recent years, the companies have been cooperating and sharing information and are key members and supporters of the SRWC Operational Working Group. Collectively, fiber companies have to-date established about 70,000 acres of commercial hybrid poplar plantations in the Pacific Northwest United States. While most private companies will not provide specific crop production cost information, they have allowed observation of crop production and harvesting activities to the extent that those costs can be fairly reliably estimated.

Operational woody crop plantations were collaboratively established once again in the mid1990s in Minnesota by the WesMin Resource Conservation and Development Council 


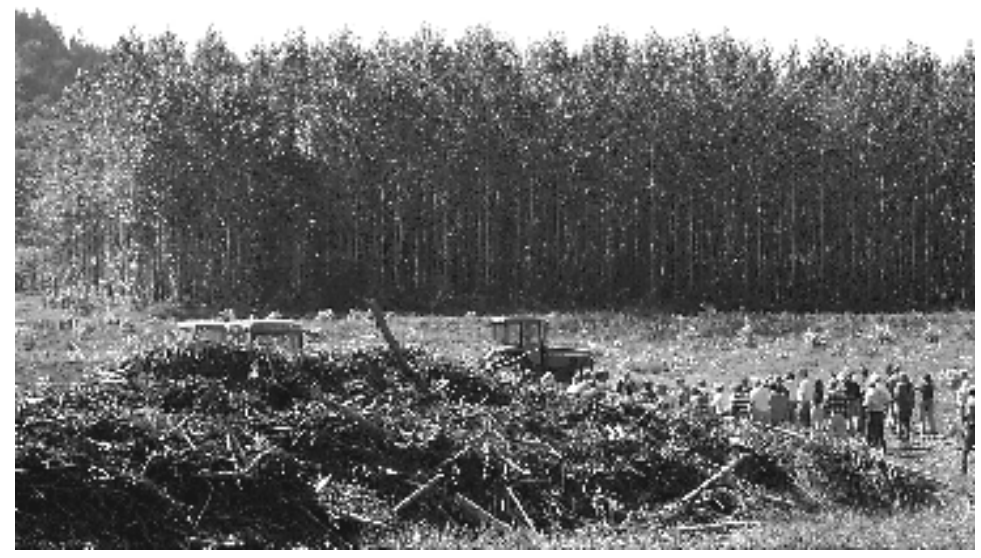

Fig. 4.1. Commercial poplar planting in the Pacific Northwest.

(RC\&D) and the USDA/FS, EPRI, and others with funding from BFDP. Approximately 2000 acres of hybrid poplar were established in 1994 and 1995 in west-central Minnesota near Alexandria on Conservation Reserve Program (CRP) land. No specific end-use (or consumer) of the fiber was identified at the time of the planting, nor have any been identified to date. Data are being collected from this acreage by BFDP researchers and by project cooperators. Detailed production activities and cost data from the Minnesota hybrid poplar planting managed by WesMin RC\&D have been published. ${ }^{126,127}$

A second, 3000-acre planting of hybrid poplar was independently established by University of Minnesota-Crookston, Agricultural Utilization Research Institute, and Minnesota Power and Light (MPL) researchers in 1995. This project involves 14 farmers near Oklee, Minnesota, in the northwest part of the state. The project was supported with state funds and facilitated by the negotiation of a 31-year contract with MPL for purchase of wood at each 10-year rotation. Production data are being collected on this project as well.

Other operational data on energy crops are being derived from integrated bioenergy demonstrations established as a result of actions of the DOE Biomass Power Program. The BFDP and other project cooperators are gathering operational data from these sites by establishing cooperative ties with the project managers and participants, by funding local individuals to assist with data collection, and by providing standardized data collection methodologies. The three projects are briefly described.

The 4000-acre switchgrass-to-energy demonstration project in south-central Iowa is growing switchgrass on CRP land to produce 3000 tons of grass for a co-firing trial in a 780-MW coal-fired power plant at Ottumwa, Iowa. This work is made possible by special waiver from the USDA to produce, manage, and harvest switchgrass on CRP land under existing contract. Switchgrass to be used for the first cofiring tests at this facility do not come from recent plantings. Currently existing plantings of switchgrass are being enhanced by weed control, re-seeding, and fertilization. Since the Ottumwa power plant is located a substantial distance from the 4000-acre switchgrass production area, the logistics of cost-effectively harvesting, handling, storing, and transporting the material to the facility is a major issue. Agricultural economists at Iowa State University are funded by BFDP to assist with collecting and analyzing the total operational cost data. 
The New York Salix Project is in the process of completing planting of nearly 500 acres of hybrid willow in western New York to provide partial wood supply to a DOE-funded co-firing project. The land is privately held farmland (mostly former dairy farmland) and does not include the use of CRP land. This DOE Biomass Power for Rural Development Project includes a component for tracking and recording the planting and field preparation costs, as well as a future component for tracking harvesting, transporting, and processing cost data. Participants in collecting the data include landowners, State University of New York (SUNY) staff, Cornell University staff, and FORECON, a timber stand improvement and forest management company that has been involved in site preparation, planting, and maintainance of most of the willows planted to date. The data are currently being compiled for BFDP on a field-by-field, operation-by-operation basis.

More than 330 acres of Alamo switchgrass has been planted on private farmland in Alabama. ${ }^{128}$ The eventual use of this grass will be for a DOE-funded co-firing test and demonstration in a coal-fired power plant in Gadsden, Alabama. BFDP is collaborating with researchers at Auburn University who are documenting costs and evaluating alternative harvest and handling techniques. The Alabama experience has shown that characteristics of switchgrass such as a clumped growth pattern and high ash content can lead to rigid, densely packed stems which cause tire damage and nonproductive down time. This problem can be easily addressed with appropriate equipment modifications and is an example of the valuable information often learned only by operational experience. This problem can be easily addressed with appropriate equipment modifications and is an example of the valuable information often learned only by operational experience.

A 50-MW biomass-fired facility using hybrid poplar may be built in Minnesota by Beck/Energy Performance Systems, Inc. The power purchase agreement with Northern States Power has been approved by the state's Public Utility Commission. Previous to this, DOE funded feasibility studies and some equipment development related to the proposed project. About 200 acres of hybrid poplar were planted in spring 2000 in support of the project. If the project overcomes financial and permitting hurdles, a planting rate of 5000 acres/year starting in 2001 is anticipated. The project could be a source of cost and risk data and provide additional opportunities for collaborative improvement of supply logistics.

\subsection{SUPPLY LOGISTICS OPERATIONAL RESEARCH AND DEVELOPMENT}

Supply logistics research focuses on the equipment, systems, and infrastructures required to economically move biomass from where it is generated to where it is used in a form needed by the end-user. Operational components include biomass collection or harvest, field handling or processing, storage, transportation, drying, and on-site handling or processing. The order of components varies according to the system, and some systems may include other operations, such as ensiling or chopping. Similar supply logistics issues apply whether feedstocks are energy crops, agricultural or forest residues, or industrial wastes, though the infrastructure involved and the equipment used varies considerably. Supply logistics research has only recently been added as a component of BFDP because it was assumed that the private sector would undertake the research as bioenergy and bioproducts markets developed. However, these markets have not developed as quickly nor in ways that were expected. With the initiation of integrated bioenergy demonstrations and with increasing requests for detailed economic analyses of potential bioenergy systems, the need for BFDP to engage in supply logistics research has been recognized. Understanding the existing supply infrastructure and limitations, transaction costs associated with biomass supply 
chains and facilitating development of new infrastructure and transaction pathways, where needed, is part of the supply logistics challenge.

Numerous opportunities exist for evaluation of the operations and supply logistics involved in supplying agricultural, forest, urban, and industrial residues and wastes to bioenergy projects. Several ethanol projects using urban and agricultural residues are in the financing and construction stages. A recent DOE solicitation for co-firing projects may create opportunities for assisting with improvement of urban and forest residue supply logistics and operational-scale data. The BFDP will be involved in these efforts pending adequate funding.

\subsubsection{Collection of Forest Thinnings and Residues}

The harvest of dead, dying, and non-merchantable wood has been proposed as a means of reducing fire risk, restoring the forest to pre-European settlement conditions, and providing a new source of income. Long-term economic and environmental sustainability of this practice is unknown. A recent BFDP project in the western United States worked with local and community groups to understand the effects of forest thinnings on water yield and the long-term flow of biomass wood from these forests. Model results indicated that the forest thinnings would have little observable effects on water quantity or quality downstream of the activities. ${ }^{129,130,131}$

\subsubsection{Agricultural Residue Supply Logistics}

The BFDP is collaborating with the National Renewable Energy Laboratory (NREL) to model the supply logistics and costs of collecting, transporting, and processing corn stover for use as an ethanol feedstock. The results will be linked to the ethanol conversion models developed by NREL to obtain full supply-chain economics.

The BFDP recently funded production of a detailed report on the supply logistics of farmers supplying corn stover to user facilities in Iowa. This report could be useful to entrepreneurs in other areas, and it also identifies potential research needs. The farmers involved have formed a company to develop a business enterprise focused on collecting and supplying corn stover for a variety of end-uses (Fig. 4.2).

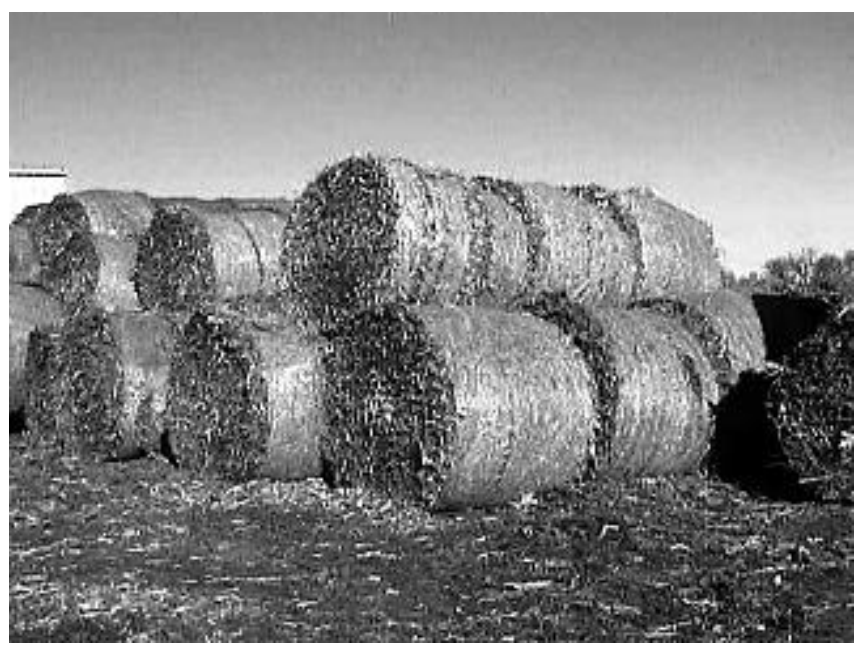

Fig. 4.2. Corn stover bales. 


\subsubsection{Energy Crop Harvest and Handling}

At the 330-acre operational switchgrass site in Alabama, a BRANCHOPTM process for harvesting and handling chopped switchgrass is being evaluated. ${ }^{128}$ This process is in contrast to the more traditional method of baling using large square or large round bales. This analysis will show comparative costs and anticipated reduced handling across the entire process.

BRANCHOP ${ }^{\mathrm{TM}}$ has potential application for other areas of the United States and other herbaceous feedstock types as well.

Traditional baling is the preferred methodology for harvesting switchgrass at the Iowa project. However, John Deere, Inc., and Vermeer Corporation are collaborating with farmers on actual inthe-field testing of new harvesting and baling equipment.

A harvester under development by Energy Performance Systems, Inc., has the potential for reducing harvest and handling costs for SRWC established in relatively large uniform plantations. ${ }^{132}$ Once the prototype is completed (proposed to be cost-shared by BFDP and DOE), the harvester will be tested on fiber company operational sites and compared with conventional SRWC harvesting systems.

Information is being collected by a European collaborator on willow harvesting systems currently in use in Europe. This information will be used to improve our economic modeling of willow crop production.

\subsubsection{Energy Crop Storage}

Information on storage costs and effects of storage on feedstock quality and storage longevity is being compiled by researchers at Prairie Lands Bio-Products, Inc., and ISU. Currently, 3000 tons of switchgrass are being stored in a single building at the Ottumwa Generating Station in Iowa.

One aspect of the BRANCHOP ${ }^{\mathrm{TM}}$ process for handling switchgrass that is being tested is whether to store large piles of harvested switchgrass outside at field sites or at a conversion facility. Options being studied include covering the piles, leaving piles uncovered, or putting piles in underground bunkers.

Studies conducted by NREL on the effects of storage of switchgrass under a variety of conditions have shown that large bales from an earlier season's field harvest tended to degrade more when exposed to large amounts of rainfall than a second harvest. It was also shown that there was little or no degradation nor weight loss when bales were stored inside. ${ }^{133}$

\subsubsection{Transactions Costs}

A recent survey of farmers in Alabama regarding their interest in producing switchgrass provided interesting results. Those expressing the most interest are crop producers rather than cattle producers - even though cattle production is generally not an economically profitable use of the land in the region. A similar survey is being planned for Iowa farmers.

In Iowa, Farmers' Cooperatives are being established. These farmer-producer-owned cooperatives may be instrumental in reducing transactions costs, facilitating information exchange and helping to develop markets and demand for their products. 


\subsubsection{Analysis and Information Exchange}

Operational research data are being used to improve and update the crop production economics model (BIOCOST) that was developed by BFDP staff. That model is being used to support potential resource cost-supply analyses and integrated systems modeling — as described in the next section on Integrated Resource Analysis and Assessment. Some operational experience and cost data are being published in reports produced by BFDP and by University subcontractors. The BFDP is continuing to maintain and organize a repository of information on the costs, risks, and environmental effects of operational conditions for energy crop production. However, the most important objective of operational crop production and supply logistics research is to assist development of economically viable bioenergy and bioproducts enterprises. Thus, much of the information gained through cost-shared BFDP operational efforts may never be officially documented or published but will be transferred directly to private industrial partners who will benefit in different ways from this information. 


\section{INTEGRATED RESOURCE ANALYSIS AND ASSESSMENT RESEARCH}

Integrated Resource Analysis and Assessment Research integrates information from, and provides input to, other BFDP tasks and DOE programs to aid in economic and policy analysis of biomass systems. The work involves creation of tools, models, and databases that can be used by firms, government agencies, and other institutions to conduct analyses pertinent to their needs. Economic and policy analysis focuses on regional and national issues; analysis is not conducted for a particular firm or site, but information is available in the form of databases and user-friendly models that can be used by individual firms to conduct screening and pre-feasibility analysis. Historically, the research has focused on dedicated energy crops; in recent years, analyses of other biomass feedstocks (i.e., forest residues, mill residues, urban wood wastes, and agricultural residues) have been included.

The research functions through collaboration with other BFDP personnel, other DOE laboratories, universities, government agencies, and researchers at other institutions. The BFDP uses consistent, standard methodologies and assumptions, and where feasible, existing models. This enhances the credibility of the analyses, facilitates the acceptance and use of the information, and helps to alleviate the problem of comparing apples and oranges that is frequently encountered when using information obtained from different sources. To increase flexibility in the types of questions that can be addressed, models and databases are developed in a way that facilitates their linkage in various combinations.

\subsection{DATABASES}

Currently, BFDP has developed two biomass resource databases that are available for use by other researchers, agencies, and firms. The Oak Ridge Energy Crop County Level Database (ORECCL) includes general information, at a county level, about current agricultural land uses and agricultural lands that are suitable for energy crop production. Also included in the database is information about three energy crops - switchgrass, hybrid poplar, and willow_ including expected yields and range and estimated production costs. The database and documentation are available on the BFDP web site (http://bioenergy.ornl.gov/bfdpmain.html). The database is periodically updated to reflect new information. ${ }^{134}$

The Multi-Feedstock Biomass Resource Database contains estimated price and quantity data for forest residues, mill residues, urban wood wastes, agricultural residues, and dedicated energy crops. Information is currently at a state level and includes quantities available at selected delivered prices $(\$ 20, \$ 30, \$ 40, \$ 50 / \mathrm{dt}$ and assuming an average $\$ 8-10 / \mathrm{dt}$ transport cost). The estimates are supported by individual resource models, and the database is currently being refined to include sub-state information and narrower price intervals. The database and documentation are currently available upon request and are being placed on the BFDP web site. Figure 5.1 summarizes the information in the database. ${ }^{135}$

\subsection{ECONOMIC MODELS}

The task has developed several models that can be used to evaluate different economic and policy issues relevant to biomass systems. BIOCOST is an Excel ${ }^{\mathrm{TM}}$-based budget-generator model used to estimate regional costs of producing switchgrass, hybrid poplar, and willow. ${ }^{136}$ 


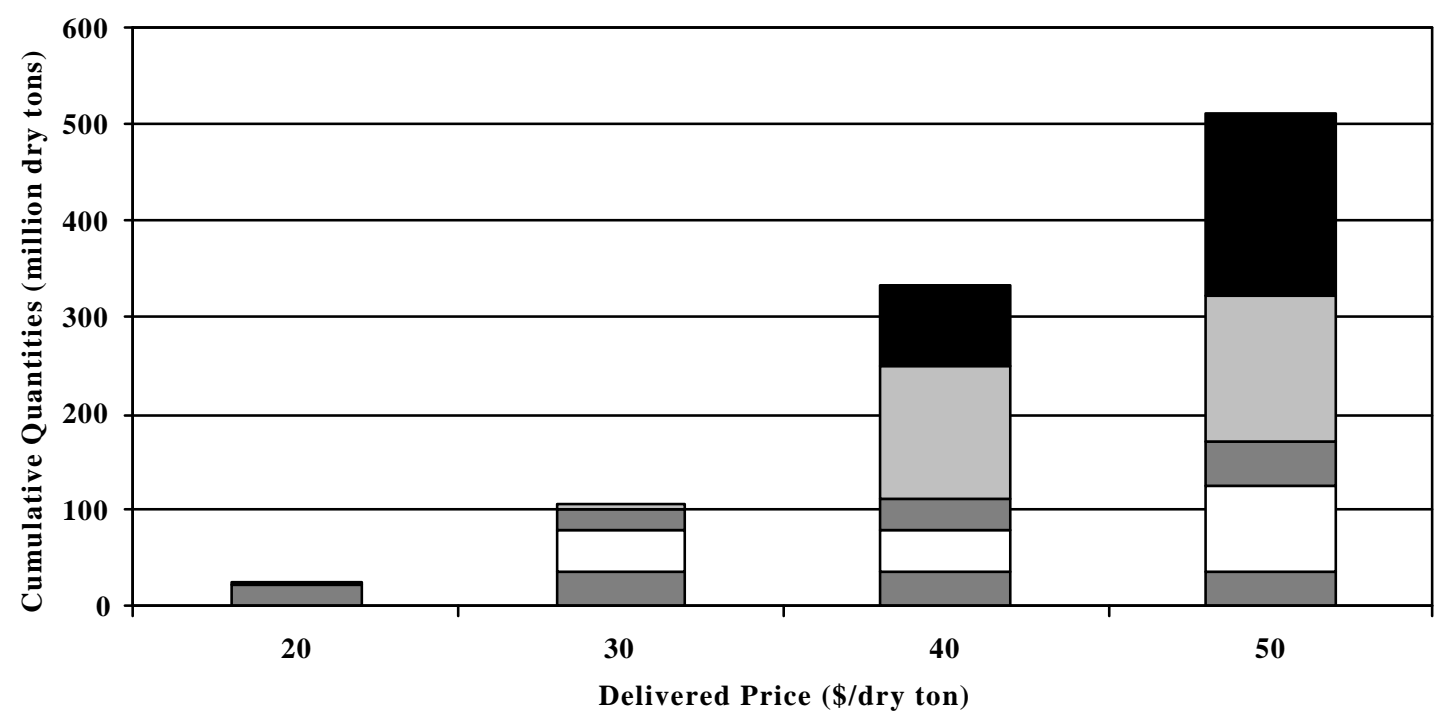

$\square$ Urban Wastes $\square$ Mill Residues $\square$ Forest Residues $\square$ Ag Residues $\square$ Energy Crops

Fig. 5.1. Potential available biomass quantities in 2000.

The model is a full-economic-cost model and uses methodology consistent with that used by USDA to estimate the costs of producing traditional agricultural crops which facilitates the comparison of energy crop production costs with those of traditional agricultural crops. Full economic costs include all variable cash costs (i.e., seeds, fuel, fertilizer, chemicals, etc.), all fixed cash costs (overhead, taxes, insurance, interest payments), and opportunity costs (equipment depreciation, producer's own labor, non-land capital costs, and land costs). The model includes default values, but users can change nearly all input parameters to tailor the estimates to their specific situation. The model is periodically updated and modified to include new information gained from research and operational studies. BIOCOST is available upon request. In collaboration with REAP Canada (Resource Efficient Agricultural Production), a Canadian version of BIOCOST is also available. BIOCOST-Canada estimates production costs for switchgrass and willow in eastern Canada and includes a soil carbon sequestration component. ${ }^{137}$ A modified version of BIOCOST has been used to estimate the cost of the whole tree harvest system. ${ }^{138}$

The Oak Ridge Integrated Biomass Assessment System (ORIBAS) is a Geographic Information System (GIS)-based transportation model. ${ }^{139,} 140$ The model incorporates a complete road network for each state, and transportation costs are estimated as a function of the technology used, time needed, and distance traveled. Using information about the geographic distribution of feedstocks within a region, the average cost of the feedstock by location, and the quantity of feedstock required by a user facility, ORIBAS can be used to estimate the cost of delivering the needed quantities of feedstock to a user facility. The model can be used to identify locations with the least-cost feedstocks and can be used to explore impacts on delivered feedstock costs resulting from the existence of multiple facilities in a region competing for the same feedstock. 


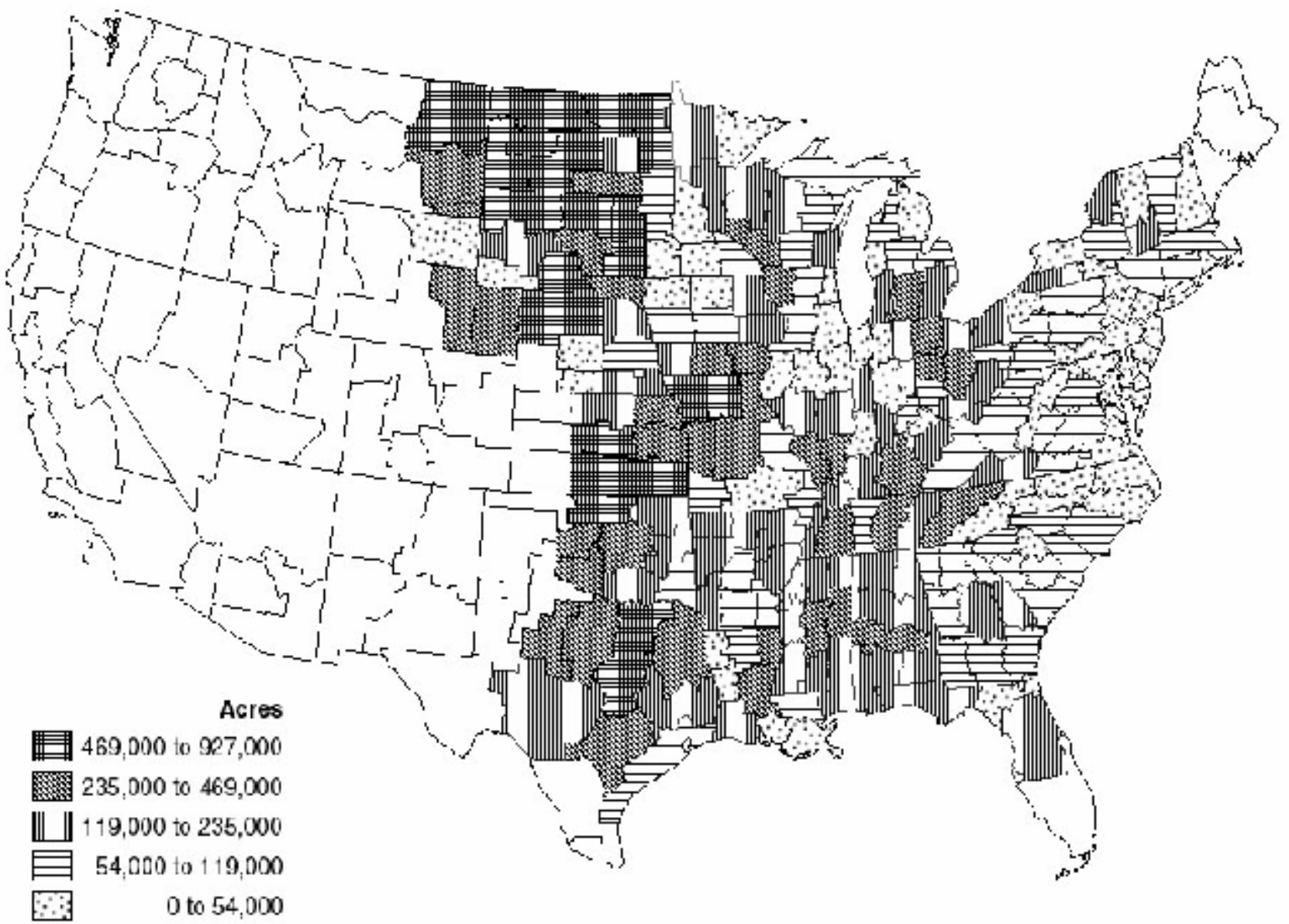

Fig. 5.2. Bioenergy crop production (assuming the production production scenario on Conservation Reserve Program acres), \$40/dt, year 2008). 
Currently under development, the Biomass Resource Logistics Model will be used to estimate the optimum combination of biomass resource collection, transportation, storage, and handling technologies to minimize feedstock costs to an user facility requiring a given annual feedstock quantity and considering the distribution density of the feedstock around the facility. When completed, it is anticipated that the model will be available on request.

The Policy Analysis System (POLYSYS) is an agricultural sector model used to estimate the cost-competitiveness and impacts of biomass crops with traditional agricultural land uses. ${ }^{141}$ The POLYSYS model includes all of the major crops, derivatives markets, livestock sector, and food, feed, industrial, and export demand. It includes the major cropland categories (i.e., land currently cropped, idled, in pasture, or in the Conservation Reserve Program). In a joint project between DOE and USDA, in collaboration with the University of Tennessee, the POLYSYS model has been modified to include switchgrass, hybrid poplar, and willows. The modified model can be used to evaluate the price needed to make energy crops competitive with traditional agricultural land uses; evaluate the impacts of energy crop production on traditional crop production quantities, location, and price, and on net farm income; and examine the impacts of agricultural and energy policies on the competitiveness of bioenergy crop production. ${ }^{142}$

\subsection{ECONOMIC AND POLICY ANALYSES}

The databases and economic models developed are currently being used in several economic and policy analyses. In addition, the information generated from these analytical efforts is being used by other researchers in numerous other studies.

The economic potential for, and the potential impacts of, bioenergy crop production have been evaluated using the POLYSYS model with inputs from ORECCL and BIOCOST. The analysis indicates that at a $\$ 40 / \mathrm{dt}$ farmgate price, approximately 42 million acres (23.4 from land in current

crops, 12.9 from Conservation Reserve Program, and 5.6 from idled and pasture) equivalent to 188 million dry tons of production, could be produced at a profit greater than existing uses for the land. Traditional crop prices are expected to increase 9 to 14 percent over projected prices without bioenergy crop production, and net farm income increases by $\$ 6$ billion annually. ${ }^{143,144}$ Figure 5.2 shows the location of bioenergy crop production.

Use of the CRP to produce and harvest bioenergy crops is often suggested as an effective means to introduce biomass crops to the agricultural sector and to supply low-cost feedstocks to user facilities, because part of the production cost would be covered by the annual CRP rental payment. To evaluate this potential, the USDA and DOE jointly developed energy crop management practices and CRP program options that could be incorporated into the POLYSYS model. The analysis indicates substantial potential to use CRP acres to produce biomass energy crops (i.e., 6.2 million acres at $\$ 30 / \mathrm{dt}$ and assuming a management practice designed to achieve high wildlife diversity and 12.9 million acres at $\$ 40 / \mathrm{dt}$ using a management practice designed to achieve high biomass productivity). Results of the analysis were cited by Senator Harkin (D-IA) in introducing legislation to establish a pilot program to use CRP acres for biomass production. The legislation passed and USDA is currently developing protocols to manage the pilot program.

In August 1999, President Clinton signed Executive Order 13134 calling for a threefold increase in the use of bioenergy and biobased products by 2010. This goal of tripling the use of bioenergy was based principally on the information contained in the Multi-Feedstock Biomass Resource Database. This analysis as well as results from the POLYSYS model are currently being used to garner support for the initiative. 
Hybrid poplar has high potential to be used as a new fiber source in addition to being an energy and bioproducts feedstock. A joint analysis with the USDA/FS is evaluating the potential for hybrid poplar to become a fiber source, with processing residues (such as tops, limbs, and bark) used for energy. A modified POLYSYS model is being combined with several Forest Service models, such as NAPAP (paper/pulp) and TAMM/ATLAS (forest inventory and roundwood), to evaluate the potential for hybrid poplar to become a joint fiber/energy source and to evaluate the potential impact this might have on the agricultural sector and on forest harvest. Preliminary results for paper and pulp use only indicate that over the next fifty years hybrid poplar could become a significant fiber source (Fig. 5.3). ${ }^{145,146}$

Corn stover, the aboveground non-grain parts of corn, is an existing biomass feedstock that could be collected and used, among other things, to produce ethanol as a liquid transportation fuel. A study is currently analyzing the potential economic impacts that could result from developing a corn-stover-to-ethanol industry in the ten Midwestern states that produce the greatest quantities of corn. The study combines the Multi-Feedstock Biomass Resource Database, ORIBAS, conversion costs from the National Renewable Energy Laboratory (NREL), and IMPLAN, a regional input-output model, to estimate the direct, indirect, and induced employment, value-added, and total economic output resulting from the establishment of the corn stover industry. Analysis is conducted for each state and includes one-time impacts associated with the construction of the ethanol plant, as well as annual impacts associated with plant operation, the agricultural sector, and the transportation sector. Fig. 5.4 shows the effect of ethanol facility size on the price of corn stover for the first 15 least expensive locations in Iowa.

Utilizing the Multi-Feedstock Biomass Resource Database and ORCED, an ORNL electricity generation and distribution model, the task is evaluating the potential for co-firing biomass in coal electricity plants. Because existing coal plants are fixed as to their geographic

location, this study will match the availability of biomass feedstocks with coal plant location. The study will analyze whether sufficient resources are available within a given radius of existing coal plants, whether the price is competitive, and if not, what policies might need to be implemented to improve the potential for co-firing.

In addition to the policy analysis, databases provide biomass resource information for use in economic and policy studies supported by other groups. Among these studies are the Ethanol Evolution Study funded by the U.S. DOE's Office of Transportation Technologies (DOE-OTT); the Transition to Alternative Fueled Vehicle Study funded by the DOE Office of Policy (OP); the National Energy Model System funded by the DOE's Energy Information Agency (EIA); the Tellus Institute Evaluation of the Kyoto Protocol funded by the U.S. Environmental Protection Agency (EPA); the Union of Concerned Scientists Renewable Energy Study; several Biomass Life Cycle Assessments funded by University of California-Davis, National Renewable Energy Laboratory, and Argonne National Laboratory; the Forest and Agriculture Sector Optimization Model funded by the EPA; and the BioEnergy Assessment Model (BEAM) funded by the International Energy Agency.

\subsection{FUTURE RESEARCH DIRECTIONS}

Integrated resource analysis and assessment research will continue to expand and improve models that estimate biomass resource supplies, particularly with respect to the less expensive feedstocks, such as urban wood wastes and mill residues. Work will expand to include more biomass demand-side analysis and to integrate the demand and supply analysis in a general equilibrium framework. Greater emphasis will be placed on evaluating the biorefinery concept that allows for simultaneous production of multiple products. Another area of future research involves 


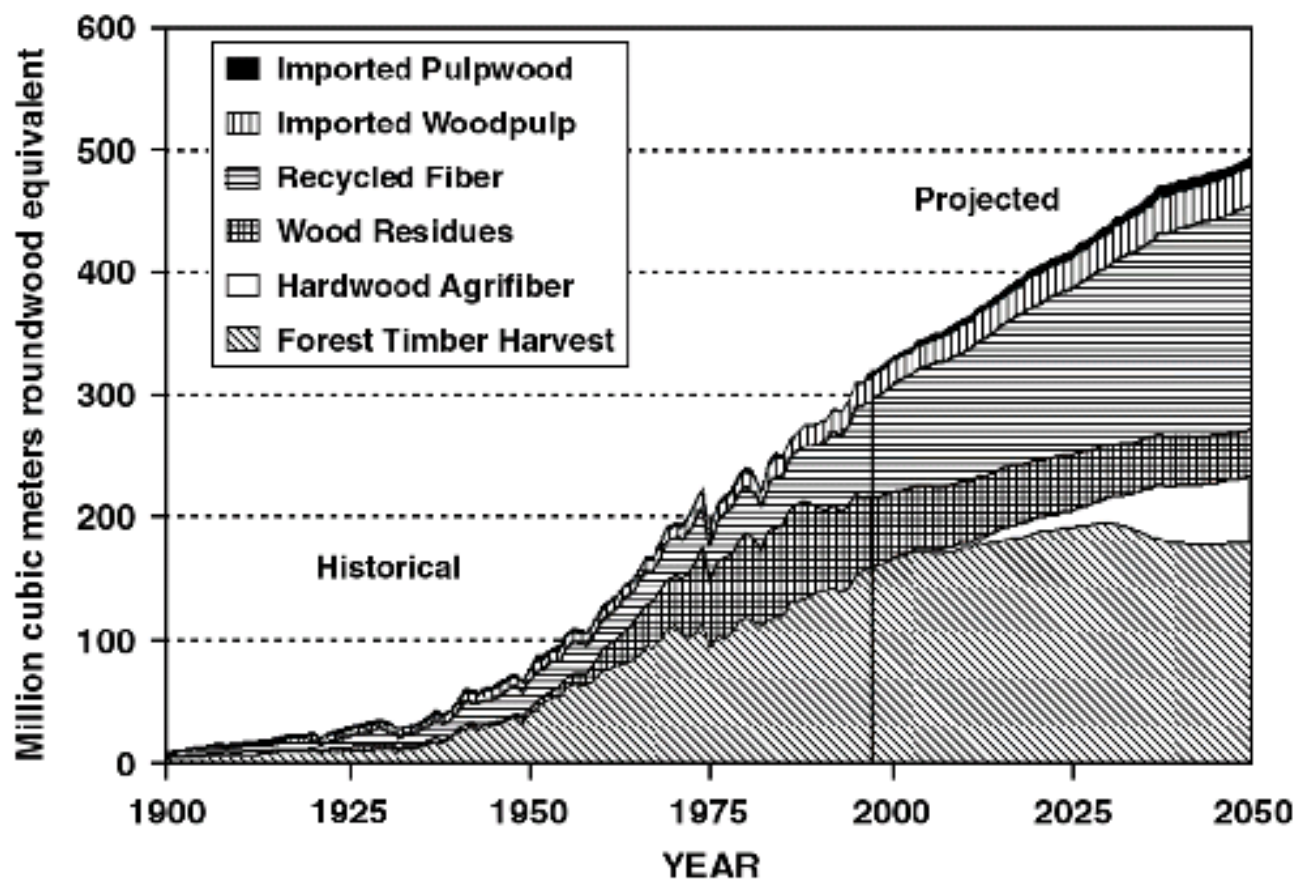

Fig. 5.3. Consumption of wood and fiber raw materials in pulp, paper, and paperboard production in the United States, 1900-2050.

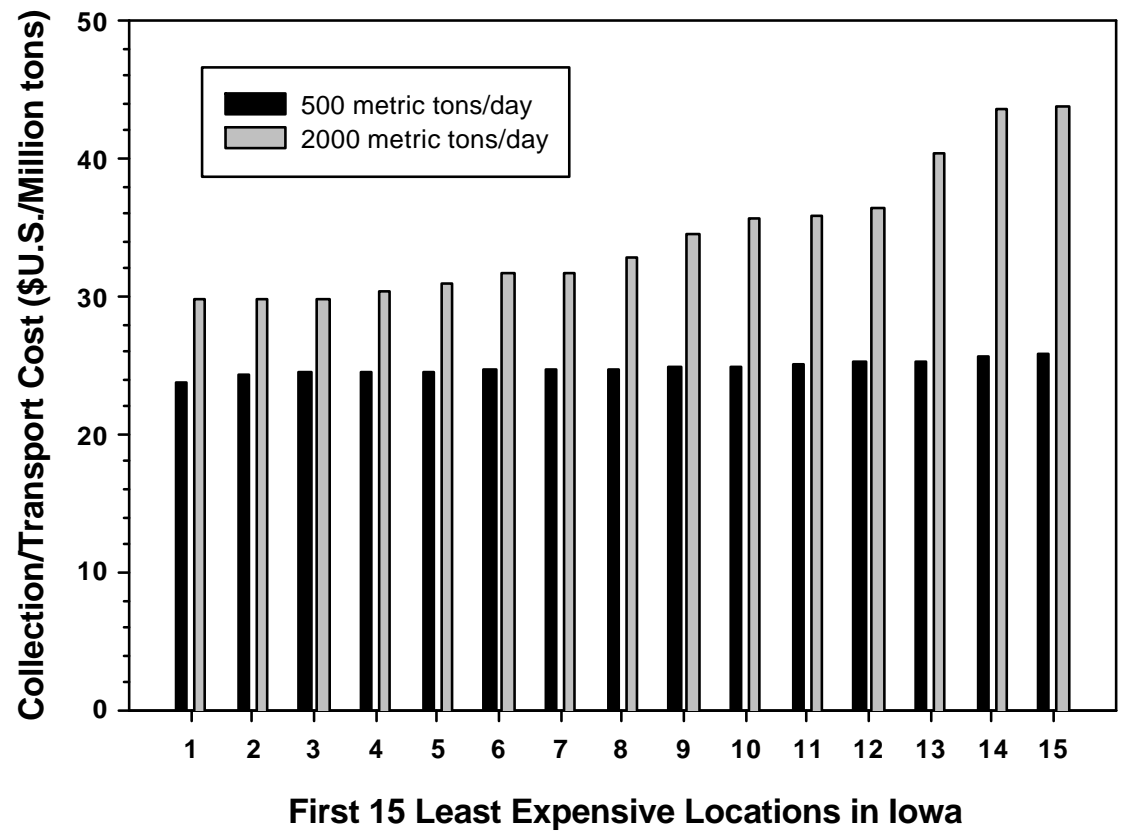
available)

Fig. 5.4. Effects of facility size on corn stover price $(50 \%$ corn acres 
integrating environmental and economic models. This analysis will include using economic models to determine changes in land-use patterns and management practices and linking these changes with environmental models to determine potential environmental impacts at a regional or national level. A final area of new research includes risk assessment, such as ways in which energy crop production can diversify farm income risk and evaluation of market risks associated with price volatility of biomass resources and competing feedstock and product markets. 


\section{PARTNERSHIP AND OUTREACH ACTIVITIES}

The mission of any communication from BFDP is to provide useful, accurate information products and efficient management services that enable the establishment and maintenance of effective external and internal communication and public information dissemination. This activity serves to keep DOE sponsors and diverse stakeholders aware of the accomplishments of the program and will facilitate the preparation and distribution of information materials by BFDP and DOE for the general public.

There are many areas of communication from within BFDP. Each of the task managers is involved in communication activities, and the level of annual staff time commitment can be significant in any given period. Communication may include, but is not restricted to, farm show participation, International Energy Agency task participation, contributions to and updating of the Bioenergy Information Network, and Short Rotation Operations Working Group web sites. In addition, staff assemble information documents and publications for mailing in response to very general or very specific requests, publish the Energy Crops Forum newsletter, and assemble general or specific fact sheets or "Frequently Asked Questions" sheets. Finally, staff are involved in providing responses and requests that come via email and phone from a wide variety of customers, compilation of subject-specific information kits to enable quick turnaround to information requests, and keeping information organized so that these services can be provided efficiently. Information service activities also involve assisting other BFDP staff in creating slides; ordering reproduction of slides, viewgraphs, prints, posters, and other media products needed for professional presentation by BFDP program and task managers; and final preparation and reproduction of technical reports from all BFDP tasks.

In addition, one or more staff members have contributed consistently to the Biomass Power for Rural Development Projects with technical monitoring and contribution at numerous meetings across as many as three to five projects for over 6 years. Contribution of time may include reviewing proposals and reviewing quarterly and annual project reports, spending many hours on the phone in one-on-one calls, conference calls, or video-teleconference calls.

Several staff members have participated actively in a series of meetings with environmental constituencies across the country to provide input and to identify, define, and document interests and concerns of internal and external stakeholders relative to bioenergy crops and agricultural residues, cultivation, and harvesting practices. ${ }^{147}$ This characterization activity has focused on environmental and agricultural stakeholders.

It is important to understand the breadth and volume of BFDP cooperators to truly comprehend the volume and necessity of communication and education. The following provides a list of collaborators by U.S. geographical region and includes national and international projects.

\section{List of Current Projects and Collaborators}

\section{South Central and Southeast Region}

Basic switchgrass genetics and physiology research:

Oak Ridge National Laboratory, University of Tennessee, Texas A\&M

University, Oklahoma State University

Midsouth switchgrass variety trials and crop management studies:

Auburn University, University of Georgia 
South Central switchgrass variety trials and crop management studies:

Texas A\&M University, USDA-Agriculture Research Service, USDA-Agriculture Extension, USDA-Plant Materials Centers

South Central switchgrass breeding and selection:

Oklahoma State University

Switchgrass biotechnology:

University of Tennessee, Oak Ridge National Laboratory

Upper Southeast switchgrass variety trials and crop management studies: Virginia Tech, University of Tennessee, University of Kentucky, West Virginia University

Physiology, biochemistry and subsurface nutrient movement in irrigated short-rotation woody crops:

Oak Ridge National Laboratory, Union Camp Corporation, USDA Forest Service

Poplar breeding for the Southeast:

University,

USDA Forest Service, Mississippi State University, Louisiana State

University of Florida, Boise Cascade Corp., Champion International Corp., International Paper Co., International Forest Seed Co., James River Corp., Scott Paper Co., Union Camp Corp., Westvaco Corp.

Nutrient fate and water quality associated with hardwood crop production:

Oak Ridge National Laboratory, Union Camp Corp., USDA Forest

Service, North Carolina State University

Effects of energy crops on soil erosion:

Alabama A\&M University, Tennessee Valley Authority, Mississippi State

University, University of Tennessee

Environmental monitoring:

National Audubon Society, Union Camp Corp., Clark University

Use of pulp mill residues as soil amendments:

National Council for Air \& Stream Improvement, Clemson University

\section{Northeast Region}

Development of hybrid willow production systems:

State University of New York, Niagara Mohawk Power Corp., NY

State Electric \& Gas Corp., NY State Energy Research \& Development

Authority, Electric Power Research Institute, Empire State Electric

Research Corp., Burlington Electric Dept., USDA Forest Service 


\section{North Central Region}

Basic physiology of hybrid poplars in North Central Region:

USDA Forest Service, University of Minnesota, Iowa State University

Bird and mammal use of poplar plantations:

USDA Forest Service, University of Minnesota, Natural Resources

Research Institute, WesMin Resource Conservation \& Development

District

Clonal trials of hybrid poplars - field sites in four states:

USDA Forest Service, Iowa State University, University of Minnesota, University of Wisconsin, Michigan State University, Wisconsin Dept. of Natural Resources

Hybrid poplar disease monitoring and studies in North Central Region:

USDA Forest Service, Iowa State University, University of Minnesota, University of Wisconsin, Michigan State University

Wood Energy Scale-Up Project:

WesMin RC\&D Council, USDA, USDA Forest Service, University of Minnesota, Minnesota Dept. of Natural Resources, Agricultural Utilization Research Institute

Poplar breeding for North Central Region:

Iowa State University, Iowa Dept. of Natural Resources

Poplar Physiology Modeling:

USDA Forest Service

Switchgrass development for Midwest/Plains:

USDA Agricultural Research Service, Iowa State University

Purdue University, University of Nebraska

Switchgrass scale-up, agronomic and economic research:

Iowa State University, Chariton Valley $R C \& D$ Council

Nutrient, water, and pesticide cycling in energy crops:

USDA Forest Service, University of Minnesota, Natural Resources

Research Institute

Soil characterization under short rotation woody crops:

USDA Forest Service, University of Minnesota-Duluth Natural Resources Research Institute

Watershed level water quality modeling for energy crops:

Purdue University 


\section{Pacific Northwest Region}

Biochemical control of drought resistance in poplars:

Oak Ridge National Laboratory, Boise Cascade Corp.

Poplar molecular genetics cooperative:

University of Washington, James River Corp., Boise Cascade Corp., Georgia Pacific Corp., Washington State University, Alberta Pacific, U.S. Forest Service Rhinelander, British Columbia Ministry of Forests, MacMillan Bloedel of America, Nippon Paper Co., Weyerhaeuser Co., Scott Paper Ltd.

Poplar physiology and genetics for Pacific Northwest: University of Washington, Washington State University

Tree genetic transformation cooperative:

Oregon State University, Weyerhaeuser, Potlatch, Crown Pacific Corp., Boise Cascade Corp., Willamette Industries, James River, MacMillan Bloedel, Union Camp Corp., Georgia Pacific Corp.

\section{National and International Projects}

Modeling of energy crop production and agricultural residues:

Oak Ridge National Laboratory, University of Tennessee

Waste and residue assessments:

Oak Ridge National Laboratory, University of Tennessee, Regional Biomass Energy Program, National Renewable Energy Laboratory

IEA Short Rotation Crops Task:

Oak Ridge National Laboratory and many of the previously listed organizations 


\section{REFERENCES}

1. Ranney, J. W., L. L. Wright, J. L. Trimble, R. D. Perlack, D. H. Dawson, C. R. Wenzel, and D. T. Curtin. 1985. Short Rotation Woody Crops Program: Annual progress report for 1984. ORNL-6160. Oak Ridge National Laboratory, Oak Ridge, Tennessee.

2. Ranney, J. W., and J. H. Cushman. 1982. Short Rotation Woody Crops Program: Annual progress report for 1981. ORNL/TM-8120. Oak Ridge National Laboratory, Oak Ridge,

Tennessee.

3. Ranney, J. W., J. H. Cushman, and J. L. Trimble. 1982. The Short Rotation Woody Crops Program: 1982 Program Summary. ORNL-5916. Oak Ridge National Laboratory, Oak Ridge, Tennessee.

4. Ranney, J. W., J. L. Trimble, L. L. Wright, R. D. Perlack, C. R. Wenzel, and J. H. Cushman. 1984. Short Rotation Woody Crops Program: Annual progress report for 1983. ORNL-6085. Oak Ridge National Laboratory, Oak Ridge, Tennessee.

5. Ranney, J. W., J. L. Trimble, L. L. Wright, P. A. Layton, R. D. Perlack, C. R. Wenzel, and D. T. Curtin. 1986. Short Rotation Woody Crops Program: Annual progress report for 1985. ORNL-6254. Oak Ridge National Laboratory, Oak Ridge, Tennessee.

6. Ranney, J. W., L. L. Wright, P. A. Layton, W. A. McNabb, C. R. Wenzel, and D. T. Curtin. 1987. Short Rotation Woody Crops Program: Annual progress report for 1986. ORNL-6348. Oak Ridge National Laboratory, Oak Ridge, Tennessee.

7. Ranney, J. W., A. R. Ehrenshaft, P. A. Layton, W. A. McNabb, and L. L. Wright. 1988. Short Rotation Woody Crops Program: Annual progress report for 1987. ORNL-6440. Oak Ridge National Laboratory, Oak Ridge, Tennessee.

8. Wright, L. L., T. W. Doyle, P. A. Layton, and J. W. Ranney. 1989. Short Rotation Woody Crops Program: Annual progress report for 1988. ORNL-6594. Oak Ridge National Laboratory, Oak Ridge, Tennessee.

9. Wright, L. L., and A. R. Ehrenshaft. 1990. Short Rotation Woody Crops Program: Annual progress report for 1989. ORNL-6625. Oak Ridge National Laboratory, Oak Ridge, Tennessee.

10. Ranney, J. W., L. L. Wright, and P. A. Layton. 1987. Hardwood energy crops: The technology of intensive culture. J. Forestry 85(9):17-28.

11. Ashby, W. C., D. F. Bresnan, R. K. Kjelgren, P. L. Roth, J. E. Preece, and C. A. Huetteman. 1993. Coppice growth and water relations of silver maple. Biomass and Bioenergy 5(5):317-323.

12. Ashby, W. C., D. F. Bresnan, P.L. Roth, J. E. Preece, and C. A. Huetteman. 1992. Nursery establishment, phenology and growth of silver maple related to provenance. Biomass and Bioenergy 3(1):1-7. 
13. DeBell, D. S., T. G. Cole, and C. D. Whitesell. 1997. Growth, development, and yield in pure and mixed stands of Eucalyptus and Albizia. Forest Science 43(2):286-298.

14. Bongarten, B. C., D. A. Huber, and D. K. Apsley. 1992. Environmental and genetic influences on short-rotation biomass production of black locust (Robinia pseudoacacia L.) In the Georgia piedmont. 1992. Forest Ecology and Management 55(1-4):315-331.

15. Johnsen, K. H., and B. C. Bongarten. 1992. Relationships between nitrogen-fixation and growth in Robinia pseudoacacia seedlings - A functional growth-analysis approach using $\mathrm{N}^{15}$. Physiologia Plantarum 85(1):77-84.

16. Harrington, C. A., and D. S. DeBell. 1995. Effects of irrigation, spacing and fertilization on flowering and growth in young Alnus rubra. Tree Physiology 15(7-8):427-432.

17. Hibbs, D. E., D. S. DeBell, and R. F. Tarrant (eds.). 1994. The biology and management of red alder. Oregon State University Press, Corvallis Oregon.

18. Patch, N. L., and P. Felker. 1997. Silvicultural treatments for sapling mesquite (Prosopis glandulosa var. glandulosa) to optimize timber production and minimize seeding encroachment. Forest Ecology and Management 96(3):231-240.

19. Patch, N. L. and P. Felker. 1997. Influence of silvicultural treatments on growth of mature mesquite (Prosopis glandulosa var. glandulosa) nine years after initiation. Forest Ecology and Management 94(1-3):37-46.

20. Tang, Z. M., and S. B. Land. 1996. Early growth, leaf development, and dry-weight production of sycamore rooted cuttings. Biomass and Bioenergy 10(4):221-229.

21. Cushman, J. H., J. J. Elmore, and A. R. Turhollow. 1985. Herbaceous Energy Crops Program: Annual progress report for FY 1984. ORNL-6221. Oak Ridge National Laboratory, Oak Ridge, Tennessee.

22. Cushman, J. H., A. R. Turhollow, and J. W. Johnson. 1986. Herbaceous Energy Crops Program: Annual progress report for FY 1985. ORNL-6263. Oak Ridge National Laboratory, Oak Ridge, Tennessee.

23. Cushman, J. H., A. R. Turhollow, and J. W. Johnson. 1987. Herbaceous Energy Crops Program: Annual progress report for FY 1986. ORNL-6369. Oak Ridge National Laboratory, Oak Ridge, Tennessee.

24. Cushman, J. H., A. R. Turhollow, and J. W. Johnson. 1989. Herbaceous Energy Crops Program: Annual progress report for FY 1987. ORNL-6514. Oak Ridge National Laboratory, Oak Ridge, Tennessee.

25. Cushman, J. H. 1991. Selecting herbaceous energy crops for the southeast and midwest/lake states. pp. 465-479. In Proceedings, Energy from Biomass and Wastes XIV. D. L. Klass (ed.). Institute of Gas Technology, Chicago, Illinois. 
26. Turhollow, A. F., J. H. Cushman, and J. W. Johnston. 1990. Herbaceous Energy Crops Program: Annual progress report for FY 1988. ORNL-6639. Oak Ridge National Laboratory, Oak Ridge, Tennessee.

27. Wright, L. L., J. H. Cushman, A. R. Ehrenshaft, S. B. McLaughlin, W. A. McNabb, J. W. Ranney, G. A. Tuskan, and A. F. Turhollow. 1992. Biofuels Feedstock Development Program annual progress report for 1991. ORNL-6742. Oak Ridge National Laboratory, Oak Ridge, Tennessee.

28. Parrish, D. J., D. D. Wolf, W. L. Daniels, D. H. Vaughan, and J. S. Cundiff. 1990. Perennial species for optimum production of herbaceous biomass in the Piedmont. ORNL/Sub/85-27413/5. Oak Ridge National Laboratory, Oak Ridge, Tennessee.

29. Parrish, D. J., D. D. Wolf, and W. L. Daniels. 1991. A five-year screening study of herbaceous energy crops. pp. 447-262. In Proceedings, Energy from Biomass and Wastes XIV. D. L. Klass (ed.). Institute of Gas Technology, Chicago, Illinois.

30. Parrish, D. J., D. D. Wolf, and W. L. Daniels. 1993. Perennial species for optimum production of herbaceous biomass in the Piedmont. ORNL/Sub/85-27413/7. Oak Ridge National Laboratory, Oak Ridge, Tennessee.

31. Sladden, S. E., D. I Bransby, and G. E. Aiken. 1991a. Biomass yield, composition and production costs for 8 switchgrass varieties in Alabama. Biomass and Bioenergy 1(2):119-122.

32. Sladden, S. E., D. I Bransby, G. E. Aiken, and G. M. Prine. 1991b. Biomass yield, composition and winter survival of tall grasses in Alabama. Biomass and Bioenergy 1(2): $123-127$.

33. Mosjidis, J. A. 1993. Variability in biomass production and plant composition in Sericea lespedeza germplasm. ORNL/90-SG301/1. Oak Ridge National Laboratory, Oak Ridge, Tennessee.

34. Wright, N. 1990. Screening of herbaceous species for energy crop production, final report 1985-1990. ORNL/Sub/85-27411/5. Oak Ridge National Laboratory, Oak Ridge, Tennessee.

35. Collins, M. 1994. Biomass production by fescue and switchgrass alone and in mixed swards with legumes-Final report. ORNL/Sub/88-SC617. Oak Ridge National Laboratory, Oak Ridge, Tennessee.

36. Meyer, D. W., Norby, W. E., Erickson, D. O., and Johnson, R. G. 1994. Evaluation of herbaceous biomass crops in the Northern Great Plains (Final Report). ORNL/Sub/88-SB844/2. Oak Ridge National Laboratory, Oak Ridge, Tennessee.

37. Wright, L. L., J. H. Cushman, A. R. Ehrenshaft, S. B. McLaughlin, W. A. McNabb, J. W. Ranney, G. A. Tuskan, and A. F. Turhollow. 1993. Biofuels Feedstock Development Program annual progress report for 1992. ORNL-6781. Oak Ridge National Laboratory, Oak Ridge, Tennessee. 
38. Wright, L. L. 1994. Production status of woody and herbaceous crops. Biomass Bioenergy 6:191-209.

39. Wright, L. L., and G. A. Tuskan. 1997. Strategy, results, and directions for woody crop research funded by the US Department of Energy. pp. 791-799. In Proceedings 1997 Pulping Conference. TAPPI Press, Atlanta, Georgia.

40. Tuskan, G. A. 1998. Short-rotation woody crop supply systems in the United States: What do we know and what do we need to know? Biomass and Bioenergy 14(4):307-315.

41. Stettler, R., R. C. Fenn, P. E. Heilman, and B. J. Stanton. 1988. Populus trichocarpa X Populus deltoides hybrids for short-rotation culture: variation patterns and 4-year field performance. Can. J. For. Res. 18:745-753.

42. Land, S. B., Jr., W. W. Elam, and M. Khan. 1995. Rejuvenated sycamore cuttings for energy plantations. Biomass and Bioenergy 8:225-264.

43. Bongarten, B. C., and S. A. Merkle. 1994. Optimizing energy yields in black locust through genetic selection. ORNL/Sub/86-95907/4. Oak Ridge National Laboratory, Oak Ridge, Tennessee

44. Ma, X., and M. Stine. 1999. Genetic diversity analysis of eastern cottonwood by Random Amplified Polymorphic DNA. Abstract. In Proceedings $25^{\text {th }}$ Southern Forest Tree Improvement Conference, July 11-15, 1999. New Orleans, Louisiana.

45. Warwell, W. V., G. R. Alker, D. L. Rockwood, S. B. Land, Jr., and M. Stine. 1999. Culture and genetic influences on greenwood cutting propagation of a new collection of eastern cottonwood in the South. In Proceedings $25^{\text {th }}$ Southern Forest Tree Improvement Conference, July 11-15, 1999. New Orleans, Louisiana.

46. Tharakan, P. J., L. P. Abrahamson, J. G. Isebrands, and D. J. Robison. 1998. First-year growth and development of willow and poplar bioenergy crops as related to foliar characteristics. pp. 1170-1180. In BioEnergy '98: Expanding BioEnergy Partnerships. Proceedings of the $8^{\text {th }}$ Biennial Conference, Madison, Wisconsin, October 4-8, 1998. Great Lakes Regional Biomass Energy Program, Chicago, Illinois.

47. Dinus, R. J., and G. A. Tuskan. 1997. Integration of molecular and classical genetics: A syntergistic approach to tree improvement. pp. 220-235. In Micropropagation, genetic engineering, and molecular biology of Populus. N. B. Klopfenstein, Y. W. Chun, M.-S Kim, and M. R. Ahuja (eds.). Gen. Tech. Rep. RM-GTR-297, U. S. Department of Agriculture, Forest Service, Rocky Mountain Research Station, Fort Collins, Colorado.

48. Bradshaw, H. D., Jr., and R. F. Stettler. 1995. Molecular genetics of growth and development in Populus. IV. Mapping QTLs with large effects on growth, form and phenology traits in a forest tree. Genetics 139:963-973. 
49. Bradshaw, H. D. 1996. Molecular biology of Populus. pp. 183-199. In Biology of Populus and its implications for management and conservation. R. F. Stettler, H. D. Bradshaw Jr., P. E. Heilman, and T. M. Hickley (eds.). NRC Research Press, National Research Council of Canada, Ottawa, Canada.

50. Preece, J. E., C. A. Huetteman, W. C. Ashby, and P. L. Roth. 1991. Micro- and cutting propagation of silver maple. I. Results with adult and juvenile propagules. J. Am. Soc. Hort. Sci. 116:142-148.

51. Ostry, M. E., M. W. Hackett, C. Michler, R. Serres, and B. McCown.1994. Influence of regeneration method and tissue source on the frequency of somatic variation in Populus to infection by Septoria musiva. Plant Sci. 97:209-215.

52. Donahue, R., T. D. Davis, C. H. Michler, D. E. Riemenschneider, D. R. Carter, P. E. Marquardt, N. Sankhla, D. Sankhla, B. E. Haissig, and J. G. Isebrands. 1994. Growth, photosynthesis and herbicide tolerance of genetically modified hybrid poplar. Can. J. For. Res. 24:2377-2383.

53. James, R. R., S. P. DiFazio, A. M. Brunner, and S. H. Strauss. 1998. Environmental effects of genetically engineered woody biomass crops. Biomass and Bioenergy 114(4):403-414.

54. Scarascia-Mugnozza, G. E., R. Ceulemans, P. E. Heilman, J. G. Isebrands, R. F. Stettler, and T. M. Hinkley. 1997. Production physiology and morphology of Populus species and their hybrids grown under short rotation. II. Biomass components and harvest index of hybrid and parental species clones. Can. J. For. Res. 27:295-294.

55. Newcombe, G., H. D. Bradshaw, Jr., G. A. Chastagner, and R. F. Stettler. 1996. A major gene for resistance to Melampsor medusae f.sp. deltoidae in a hybrid poplar pedigree. Phytopathology 86(1):87-94.

56. Han, K. H., R. Meilan, C. P. Ma, and S. H. Strauss. 2000. An Agrobacterium tumefaciens transformation protocol effective on a variety of cottonwood hybrids (genus Populus). Plant Cell Reports 19(3):315-320.

57. Brunner, A. M., R. Mohamed, R. Meilan, L. A. Sheppard, W. H. Rottmann, and S. H. Struass. 1998. Genetic engineering of sexual sterility in shade trees. J. Arboricult 24(5):263-273.

58. Meilan, R., K. H. Han, C. P. Ma, R. R. James, J. A. Eaton, B. J. Stanton, E. Hoien, R. P. Crockett, and S. H. Strauss. 2000. Development of glyphosate-tolerant hybrid cottonwoods. 2000. TAPPI Journal 83(1):164-166.

59. Taliaferro, C. M., K. P. Vogel, J. H. Bouton, S. B. McLaughlin, and G. A. Tuskan. 1999. Reproductive characteristics and breeding improvement potential of switchgrass. pp. 147-153. In R. P. Overend and E. Chornet (eds.). Biomass: A Growth Opportunity in Green Energy and Value-Added Products, Vol. 1. Proceedings of the Fourth Biomass Conference of the Americas, August 29-September 2, 1999, Oakland, California. Elsevier Science Ltd., Oxford, UK. 
60. McLaughlin, J. Bouton, D. Bransby, B. Conger, W. Ocumpaugh, D. Parrish, C. Taliaferro, K. Vogel, and S. Wullschleger. 1999. Developing switchgrass as a bioenergy crop. pp. 282-299. In Perspectives on new crops and new uses. J. Janick (ed.). ASHS Press, Alexandria, Virginia.

61. Hopkins, A. A., C. M. Taliaferro, and C. D. Christian. 1996. Chromosome number and nuclear DNA content of several switchgrass populations. Crop Sci. 36:1192-1195.

62. Hultquist, S., K. P. Vogel, D. E. Lee, K. Arumuganathan, and S. Kaeppler. 1996. Chloroplast DNA and nuclear DNA content in variations among cultivars of switchgrass, Panicum virgatum L. Crop Sci. 36:1049-1052.

63. Hultquist, S., K. P. Vogel, D. E. Lee, K. Arumuganathan, and S. Kaeppler. 1997. DNA content and chloroplast DNA polymorphisms among accessions of switchgrass from remnant Midwestern prairies. Crop Sci. 37:595-598.

64. Taliaferro, C. M., and A. A. Hopkins. 1996. Breeding characteristics and improvement potential of switchgrass. pp. 41-52. In Proc. Third Liquid Fuel Conference: Liquid Fuels and Industrial Products from Renewable Resources, Nashville, Tennessee, Sept. 15-17, 1996.

65. Taliaferro, C. M., A. A. Hopkins, M. P. Anderson, and J. A. Anderson. 1996. Breeding and genetic studies in bermudagrass and switchgrass. pp. 41-52. In Proc. $52^{\text {nd }}$ Southern Pasture and Forage Crop Improvement Conference, Oklahoma City, Oklahoma, March 30-April 2, 1996.

66. Hopkins, A. A., and C. M. Taliaferro. 1997. Genetic variation within switchgrass populations for acid soil tolerance. Crop Sci. 37:1719-1722.

67. Martinez-Reyna, J. M., and K. P. Vogel. 1998. Controlled hybridization technique for switchgrass. Crop Sci. 38:876-878.

68. Denchev, P. D., and B. V. Conger. 1994. Plant regeneration from callus cultures of switchgrass. Crop Sci. 34:1623-1627.

69. Denchev, P. D., and B. V. Conger. 1995. In vitro culture of switchgrass: Influence of 2,4-D and picloram in combination with benzyl adenine on callus initiation and regeneration. Plant Cell Tissue Organ Cult. 40:43-48.

70. Alexandrova, K. S., P. D. Denchev, and B. V. Conger. 1996. In vitro development of inflorescences from switchgrass nodal segments. Crop Sci. 36:175-178.

71. Alexandrova, K. S., P. D. Denchev, and B. V. Conger. 1996. Micropropogation of switchgrass by node culture. Crop Sci. 36:1709-1711.

72. Dutta Gupta, S., and B.V. Conger. 1998. In vitro differentiation of multiple shoot clumps from intact seedlings of switchgrass. In Vitro Cell. Dev. Biol. —Plant 34(3):196-202.

73. Dutta Guppta S., and B. V. Conger. 1999. Somatic embryogenesis and plant regeneration from suspension cultures of switchgrass. Crop Sci. 39:223-227. 
74. Odjakova, M. K., and B. V. Conger. 1999. The influence of osmotic pretreatment and inoculum age on the initiation and regeneration of switchgrass suspension cultures. In Vitro Cell. Dev. Biol. —Plant 35:441-444.

75. Richards, H. A., V. A. Rudas, H. Sun, J. K. McDaniel, Z Tomaszewski and B. V. Conger. 2000. Construction of a GFP-BAR plasmid and its use for switchgrass transformation. Plant Cell Reports (in press).

76. Gunter, L. E., G. A. Tuskan, and S. D. Wullschleger. 1996. Diversity among populations of switchgrass based on RAPD markers. Crop Sci. 36:1017-1022.

77. Sanderson, M. A., R. L. Reed, S. B. McLaughlin, S. D. Wullschleger, B. V. Conger, D. J. Parrish, D. D. Wolf, C. Taliaferro, A. A. Hopkins, W. R. Ocumpaugh, M. A. Hussey, J. C. Read, and C. R. Tischler. 1996. Switchgrass as a sustainable bioenergy crop. Bioresource and Technol. 56:83-93.

78. Wullschleger, S. D., M. A. Sanderson, S. B. McLaughlin, D. P. Biradar, and A. L. Rayburn. 1996. Photosynthetic rates and ploidy levels among populations of switchgrass. Crop Sci. 36:306-312.

79. Wullschleger, S. D., L. E. Gunter, and C. T. Garten. 1998. Genetic diversity, carbon/nitrogen cycling, and long-term sustainability of yield in the bioenergy crop switchgrass (Panicum virgatum). ORNL/M-6516. Oak Ridge National Laboratory, Oak Ridge, Tennessee.

80. Scurlock, J. M. O., D. C. Dayton, and B. Hames. 2000. Bamboo: An overlooked biomass resource? Biomass and Bioenergy (in press).

81. Lewandowski, I., J. Clifton-Brown, W. Huisman and J. M. O. Scurlock. 2000. Miscanthus: European experience with a novel energy crop. Biomass and Bioenergy (in press).

82. Strong, T., and E. Hansen. 1993. Hybrid poplar spacing/productivity relations in short rotation intensive culture plantations. Biomass and Bioenergy 4(4):255-262.

83. DeBell, D. S., G. W. Ceudenen, and J. C. Zasada. 1993. Growing Populus biomass: comparison of woodgrass versus wider-spaced short-rotation systems. Biomass and Bioenergy 4(5):305-314.

84. DeBell, D. S., C. A. Harrington, G. W. Clendenen, and J. C. Zasada. 1997. Tree growth and stand development of four Populus clones in large monoclonal plots. New Forests 14(1):1-18.

85. Bowersox, T. W., L. R. Stover, P. R. Blankenhorn, C. H. Strauss, and B. E. Lord. 1991. Height and diameter growth of dense Populus plantations in response to fertilization and irrigation. Biomass and Bioenergy 1(2):111-117.

86. Kopp, R. F., L. P. Abrahamson, E. H. White, K. F. Burns, and C. A. Nowak. 1997. Cutting cycle and spacing effects on biomass production by a willow clone in New York. Biomass and Bioenergy 12(5):313-319. 
87. Kopp, R. F., L. P. Abrahamson, E. H. White, C. A. Nowak, L. Zsuffa, and K. F. Burns. 1996. Woodgrass spacing and fertilization effects on wood biomass production by a willow clone. Biomass and Bioenergy 11(6):451-457.

88. Downing, M., and G. A. Tuskan. 1995. Is there a need for site production functions for shortrotation woody crop plantings? pp. 207-215. In Proceedings, Second Biomass Conference of the Americas: Energy, Environment, Agriculture, and Industry, Portland, Oregon, August 21-24, 1995. NREL/CP-200-8098, National Renewable Energy Laboratory, Golden, Colorado.

89. Ostry, M. E., and D. D. Skilling. 1988. Somatic variation in resistance of Populus to Septoria musvia. Plant Disease 72(8):724-727.

90. Ostry, M. E., R. E. McRoberts, K. T. Ward, and R. Resendez. 1988. Screening hybrid poplars invitro for resistance to leaf-spot caused by Septoria musvia. Plant Disease 72(6):497-499.

91. Ward, K. T. 1998. Molecular genetic variation in Septoria musiva and S. populicola. M. S. Thesis, University of Minnesota.

92. Sanderson, M. A., R. L. Reed, W. R. Ocumpaugh, M. A. Hussey, G. Van Esbroeck, J. C. Read, C. Tischler, and F. M. Hons. 1999. Switchgrass cultivars and germplasm for biomass feedstock production in Texas. Bioresource Technology 67(3):209-219.

93. Bransby, D. I. 1999. Effects of management factors on energy content and slagging potential of switchgrass. pp. 1435-1438. In R. P. Overend and E. Chornet (eds.), Biomass: A Growth Opportunity in Green Energy and Value-Added Products, Vol. 2. Proceedings of the Fourth Biomass Conference of the Americas, August 29-September 2, 1999, Oakland, California. Elsevier Science Ltd., Oxford, UK.

94. Wolf, D. D., and D. J. Parrish. 1994. Stratifying switchgrass seed in bulk quantities. p. 175. In Agronomy Abstracts. Am. Soc. Agron. Madison, Wisconsin.

95. Tischler, C. R., B. A. Young, and S. A. Sanderson. 1994. Techniques for reducing seed dormancy in switchgrass. Seed Sci. Techno. 22:19-26.

96. Parrish, D. J., D. D. Wolf, J. A. Balasko, J. T. Green, M. Rasnake, and J. H. Reynolds. 1999. Maximizing switchgrass biomass production. p 14. Agronomy abstracts.

97. Parrish. D. J., D. D. Wolf, P. R. Peterson, and W. L. Daniles. 1999. Successful establishment of switchgrass. Abstract. p. 25. In The Second Eastern Native Grass Symposium. Baltimore, Maryland.

98. Buhler, D. D., D. A. Netzer, D. E. Riemenschneider, and R. G. Hartzler. 1998. Weed management in short rotation poplar and herbaceous perennial crops grown for biofuel production. Biomass and Bioenergy 14(4):385-394. 
99. Sanderson, M. A., J. C. Read, and R. L. Reed. 1999. Harvest management of switchgrass for biomass feedstock and forage production. Agron. J. 91(1):5-10.

100. Wolfe, D. D., and D. A. Fiske. 1995. Planting and managing switchgrass for forage, wildlife, and conseration. Virginia Cooperative Extension Publ. 418-013, Virginia Polytechnic Institute and State University, Blacksburg, Virginia.

101. Tolbert, V. R., and L. L. Wright. 1998. Environmental enhancement of U.S. biomass crop technologies: Research results to date. Biomass and Bioenergy 15:93-100.

102. Thornton, F. C, B. R. Bock, A. D. Behel, A. Houston, and D. D. Tyler. 2000. Utilization of waste materials to promote hardwood tree growth. Southern Journal of Applied Forestry (in press).

103. Turhollow, A. 2000. Costs of producing biomass from riparian buffer strips. ORNL/TM-1999/146. Oak Ridge National Laboratory, Oak Ridge, Tennessee.

104. Joslin, J. D., and S. H. Schoenholtz. 1997. Measuring the environmental effects of converting cropland to short-rotation wood crops: A research approach. Biomass and Bioenergy 13(4/5):301-311.

105. Thornton, F. C., J. D. Joslin, B. R. Bock, A. Houston, T. H. Green, S. Schoenholtz, D. Pettry, and D. D. Tyler. 1998. Environmental effects of growing woody crops on agricultural land: First year effects on erosion and water quality. Biomass and Bioenergy 15(1):57-69.

106. Malik, R. K., T. H. Green, G. F. Brown, and D. Mays. 2000. Use of cover crops in short rotation hardwood plantations to control erosion. Biomass and Bioenergy 18:479-487.

107. Tolbert, V. R., F. C. Thornton, J. D. Joslin, B. R. Bock, W. E. Bandaranayake, D. D. Tyler, D. Pettry, T. H. Green, R. Makik, A. E. Houston, S. Schoenholtz, M. Shires, L. Binghan, and J. Dewey. 1998. Soil and water quality aspects of herbaceous and woody energy crop production: lessons from research-scale comparisons with agricultural crops. pp 1272-1281. In BioEnergy 98: Expanding BioEnergy Partnerships. Proceedings of the $8^{\text {th }}$ Biennial Conference, Madison, Wisconsin, October 4-8, 1998. Great Lakes Regional Biomass Energy Program, Chicago, Illinois.

108. Tolbert, V. R., J. E. Lindberg, T. H. Green, R. Makik, W. E. Bandaranayake, J. D. Joslin, F. C. Thornton, D. D. Tyler, A. E. Houston, D. Pettry, S. Schoenholtz, B. R. Bock, and C. C. Trettin. 1997. Soil and water quality implications of production of herbaceous and woody crops. pp. 195-206. In Proceedings IEA International Workshop on Environmental Aspects of Energy Crop Production, Brasimone, Italy, October 9-11, 1997.

109. Perry, C. H., K. N. Brooks, D. F. Grigal, J. G. Isebrands, and V. R. Tolbert. 1998. A comparison of nutrient export from short-rotation hybrid poplar plantations and natural forest stands. pp. 1252-1261. In BioEnergy '98: Expanding BioEnergy Partnerships. Proceedings of the $8^{\text {th }}$ Biennial Conference, Madison, Wisconsin, October 4-8, 1998. Great Lakes Regional Biomass Energy Program, Chicago, Illinois. 
110. Perry, C. H. 1998. Hydrologic impacts of short-rotation woody crop production in northwestern Minnesota. Ph.D. Thesis. University of Minnesota, St. Paul, Minnesota.

111. Ma, Z., C. W. Wood, and D. I. Bransby. 2000. Carbon dynamics subsequent to establishment of switchgrass. Biomass and Bioenergy 18:93-104

112. Ma, Z., C. W. Wood, and D. I. Brasby. 2000. Impacts of soil management on root characteristcs of switchgrass. Biomass and Bioenergy 18:105-112.

113. Garten, C. T., Jr., and S. D Wullschleger. 1999. Soil carbon inventories under a bioenergy crop (switchgrass): Measurement limitations. J. Environ. Qual. 28:1359-1365.

114. Garten, C. T., Jr., and S. D. Wullschleger. 2000. Soil carbon dynamics beneath switchgrass as indicated by stable isotope analysis. J. Environ. Qual. 29:645-653.

115. Tolbert, V. R., J. D. Joslin, F. C. Thornton, B. R. Bock, D. E. Pettry, W. Bandaranayake, D. Tyler, A. Houston, and S. Schoenholtz. 1999. Biomass crop production: Benefits for soil quality and carbon sequestration. pp 127-132. In R. P. Overend and E. Chornet (eds.), Biomass: A Growth Opportunity in Green Energy and Value-Added Products, Vol. 1. Proceedings of the Fourth Biomass Conference of the Americas, August 29-September 2, 1999, Oakland, California, Elsevier Science Ltd., Oxford, UK.

116. Tolbert, V. R., F. C. Thornton, J. D. Joslin, B. R. Bock, W. Bandaranayake, A. Houston, D. Tyler, D. Mays, D. E. Pettry, and T. H. Green. 2000. Increasing belowground carbon sequestration with conversion of agricultural lands to production of bioenergy crops. New Zealand J Forestry Science (in press).

117. Hoffman, W., J. Beyea, and J. H. Cook. 1995. Ecology of agricultural monocultures: Some consequences for biodiversity in biomass energy farms. pp. 1618-1627. In Proceedings Second Biomass Conference of the Americas: Energy, Environment, Agriculture, and Industry, Portland, Oregon, August 21-24, 1995. NREL/CP-200-8098, National Renewable Energy Laboratory, Golden, Colorado.

118. Hoffmann, W., J. H. Cook, and J. Beyea. 1993. Some ecological guidelines for large-scale biomass plantations. pp. 33-41. In Proceedings First Biomass Conference of the Americas: Energy, Environment, Agriculture, and Industry, Burlington, Vermont, August 30-September 2, 1993. NREL/CP-200-5768, National Renewable Energy Laboratory, Golden, Colorado.

119. Christian, D. P., P. T. Collins, J. M. Hanowski, and G. J. Niemi. 1997. Bird and small mammal use of short-rotation hybrid poplar plantations. J. Wildl. Manage. 61(1):171-182.

120. Christian, D. P., G. J. Niemi, J. M. Hanowski, and P. Collins. 1994. Perspectives on biomass energy tree plantations and changes in habitat for biological organisms. Biomass and Bioenergy 6:(1/2):31-39.

121. Hanowski, J. M., G. J. Niemi, and D. C. Christian. 1997. Influence of within-plantation heterogeneity and surrounding landscape composition on avian communities in hybrid poplar 
plantations. Conservation Biology 11(4):936-944.

122. Christian, D. P., W. Hoffman, J. M Hanowski, G. J. Niemi, and J. Beyea. 1998. Bird and mammal diversity of woody biomass plantations in North America. Biomass and Bioenergy 14(4):395-402.

123. Christian, D. P. 1997. Wintertime use of hybrid poplar plantations by deer and medium-sized mammals in the midwestern U.S. Biomass and Bioenergy 12(1):35-40.

124. Schiller, A., W. A. Cresko, J. Lindberg, V. R. Tolbert, and W. Hoffman. 2000. Bird communities on intensively managed forests from planting to harvest in the Southeastern United States. Biomass and bioenergy (submitted).

125. Netzer, Dan, and Don Riemenschneider. 2000. Personal communication. United States Forest Service, North Central Forest Experiment Station. Rhinelander, Wisconsin.

126. Downing, M. E., R. Pierce, and T. Kroll. 1994. 1994 Establishment Cost Data - Minnesota Wood Energy Scale-up Project. ORNL/TM-12914. Oak Ridge National Laboratory, Oak Ridge, Tennessee.

127. Downing, M. E., R. Stoffel, T. Kroll, and D. Langseth. 1997. Minnesota Wood Energy Scale-up Project 1995 and 1996 Establishment Cost Data. ORNL/TM-13393. Oak Ridge National Laboratory, Oak Ridge, Tennessee.

128. Bransby, D. I. 1999. Field chopping as an alternative to baling for harvesting and handling switchgrass. pp. 325. In Proceedings of the Fourth Biomass Conference of the Americas, August 29-September 2, 1999, Oakland, California, Elsevier Science Ltd., Oxford, UK.

129. Hollenstein, K., and R. L. Graham. 2000. Biomass flow from fuel treatments in western forests. Biomass and Bioenergy (in press).

130. Hollenstein, K., R. L. Graham, and W. Shepperd. 2000. Simulating biomass flow from fuel treatment thinnings in western Forests. Journal of Forestry (in press).

131. Hollenstein, K., and R.L. Graham. 2000. Fuel treatment thinning for bioenergy: An overview. Draft ORNL/TM. Oak Ridge National Laboratory, Oak Ridge, Tennessee.

132. Perlack, R.D., M.E. Walsh, L. L. Wright, and L. D. Ostlie. 1996. The economic potential of whole-tree feedstock production. Bioresource Technology. 55:223-229.

133. Sanderson, M. A., Egg, R. P., and Wiselogel, A. E. 1997. Biomass Losses During Harvest and Storage of Switchgrass. Biomass and Bioenergy 12(2):07-114. NICH Report No. 23326.

134. Graham, R.L., and M. E. Walsh. 1998. A National Assessment of Promising Areas for Switchgrass, Hybrid Poplar, or Willow Energy Crop Production, ORNL/TM 6944, July 1998. Oak Ridge National Laboratory, Oak Ridge, Tennessee. 
135. Walsh, M. E., R. L. Perlack, A. Turhollow, D. de la Torre Ugarte, D. A. Becker, R. L. Graham, S. E. Slinsky, and D. E. Ray. 2000. Biomass Feedstock Availability in the United States, Draft ORNL/TM. Oak Ridge National Laboratory, Oak Ridge, Tennessee.

136. Walsh, M.E., and D. Becker. 1996. BIOCOST: A Software Program to Estimate the Cost of Producing Bioenergy Crops. pp. 480-486. Proceedings of Bioenergy'96-Partnerships to Develop and Apply Biomass Technologies, Nashville, Tennessee, September 15-20, 1996.

137. Girouard, P., M.E. Walsh, and D.A. Becker. 1999. BIOCOST-Canada: A New Tool to Evaluate the Economic, Energy, and Carbon Budgets of Perennial Energy Crops. pp. 85-90. In Proceedings of the Fourth Biomass Conference of the Americas, August 29-September 2, 1999, Oakland, California. Elsevier Science Ltd., Oxford, UK.

138. Perlack, R.D., M. E. Walsh, L. L. Wright, and L. D. Ostlie. 1996. The economic potential of whole-tree feedstock production. Bioresource Technology 55:223-229.

139. Graham, R.L. W. Liu, H.I. Jager, B.C. English, C.E. Noon, and M.J. Daly. 1996. A Regional-Scale GIS-Based Modeling System for Evaluating the Potential Costs and Supplies of Biomass From Biomass Crops, pp. 444-450. In Proceedings of Bioenergy '96- Partnerships to Develop and Apply Biomass Technologies, Nashville, Tennessee, September 15-20, 1996.

140. Noon, C.E., M.J. Daly, R.L. Graham, and F.B. Zhan. 1996. Transportation and Site Location Analysis for Regional Integrated Biomass Assessment (RIBA). pp. 487-493. In Proceedings of Bioenergy '96-Partnerships to Develop and Apply Biomass Technologies, Nashville, Tennessee, September 15-20, 1996.

141. de la Torre Ugarte, D., and D. Ray. 2000. Biomass and bioenergy applications of the POLYSYS modeling framework, Biomass and Bioenergy 18:291-308.

142. Walsh, M. E. 1998. U.S. Bioenergy Crop Economic Analysis: Status and Needs. Biomass and Bioenergy 14(4):341-350.

143. Walsh, M.E., D. G. de la Torre Ugarte, H. Shapouri, and S. P. Slinsky. 2000. The economic impacts of bioenergy crop production on U.S. agriculture. Environmental and Resource Economics (submitted).

144. Daniel G. de la Torre Ugarte, Marie E. Walsh, Hosein Shapouri, Stephen P. Slinsky, Personal Communication, University of Tennessee, Agricultural Policy Analysis Center, Knoxville, Tennessee.

145. Ince, P. J. 1998. A long-range outlook for U.S. paper and paperboard demand, technology and fiber supply-demand equilibria. pp. 330-343. In proceedings, Society of American Foresters National Convention, September 19-23, 1998. Society of American Foresters, Bethesda, Maryland.

146. Walsh, M.E., P.J. Ince., D. DeLa Torre Ugarte, D. Adams, R. Alig, J. Mills, H. Spelter, K. Skog, S.P. Slinsky, D.E. Ray, and R. L. Graham. 1999. Potential of Short Rotation Wood Crops 
as a Fiber and Energy Source in the U.S. pp. 63-68. In Proceedings of the Fourth Biomass Conference of the Americas, August 29 to September 2, 1999, Oakland, Calfiornia.

147. Peele, E. 2000. Biomass stakeholder views and concerns: Environmental groups and trade associations. ORNL/TM-1999/271. Oak Ridge National Laboratory, Oak Ridge, Tennessee. 